\title{
Global change and the future ocean: a grand challenge for marine sciences
}

\author{
Carlos M. Duarte $1,2,3 *$ \\ 'Department of Global Change Research, (Consejo Superior de Investigaciones Cientificas-University of the Balearic Islands) Instituto Mediterráneo de Estudios \\ Avanzados, Mallorca, Spain \\ 2 The UWA Oceans Institute, The University of Western Australia, Crawley, WA, Australia \\ ${ }^{3}$ Faculty of Biosciences, Fisheries and Economics, University of Tromsø, Tromsø, Norway \\ *Correspondence: carlos.duarte@uwa.edu.au
}

\section{Edited and reviewed by:}

Philip Boyd, University of Otago, New Zealand

Robinson W. Fulweiler, Boston University, USA

Keywords: global change, climate change, overfishing, pollution, ocean acidification

"The trouble with our times is that the future is no longer what it used to be." Paul Valery (1937)

The occurrence of a growing number of environmental changes attributable to human pressures at the planetary scale has led to the identification of these changes as part of a higher-order syndrome referred to as Anthropogenic Global Change (Steffen et al., 2006). Whereas most research on the drivers and impacts of anthropogenic global change has focused on terrestrial ecosystems, which receive $90 \%$ of research effort (Hendriks et al., 2006; Richardson and Poloczanska, 2008), the ocean is also impacted by significant pressures (Halpern et al., 2008). Some of these forcings are highly specific, such as ocean acidification (Orr et al., 2005) or overfishing (Jackson et al., 2001), while some others, such as warming, hypoxia, eutrophication, pollution and increased UV radiation are shared with terrestrial and/or freshwater ecosystems. Anthropogenic global pressures are so prevalent in the ocean (e.g., Halpern et al., 2008) that concern on the future of ocean ecosystems (Jackson et al., 2001) resonates among policy makers, who have launched a series of initiatives to address ocean health, such as the Oceans Compact initiative of the UN Secretary General (Ki-moon, 2012), the Marine Strategy Framework Directive of the EU (European Union, 2011), or the US Executive Order 13547 on the Stewardship of the Ocean, Our Coasts, and the Great Lakes (Obama, 2010). Indeed, forecasting to what extent future ecosystem will be altered is recognized as a great challenge addressed in international conferences and programs (e.g., http://www.futureocean. org). However, the scientific community involved with the assessment of global change and the future state of the ocean did not have a dedicated forum to share their results until the advent in early 2014 of the section on Global Change and the Future Ocean in Frontiers in Marine Science.

As Global Change and the Future Ocean emerges as a coherent research program, there is a need to define more formally what global change is, what its drivers are, how it manifests itself in the ocean, and how these changes are leading to a future state, or a range of possible alternative states, of the ocean. I address here these elements in an effort to articulate the grand challenge the research community addressing global change and future ocean ocean states must face.

\section{GLOBAL CHANGE: DEFINITION, CAUSES AND OPERATION DEFINITION}

Global Change is a term frequently used in the scientific literature, where it can be found, when restricted to the environment, in 105,000 articles published since 1980 in the Web of Science ${ }^{\mathrm{TM}}$ (Accessed July 26,2014 ), or about $7 \%$ of all content. A total of 35,014 of these articles address the ocean, with 9634 of these articles, of which 2334 address the ocean, published in 2013. Global Change may arise from anthropogenic pressures on the biosphere, as discussed above, but also from extremely rare but highly disruptive events. Examples of these include the impact of large asteroids believed to have caused mass extinction in the CretaceousPaleogene boundary (65 million years BP, Schulte et al., 2010), "resetting" the biosphere, or bursts of gamma rays derived from distant supernovas that might cause catastrophic mortality of ocean plankton (Peñate et al., 2010). A key distinction between anthropogenic and natural drivers of global change is that global change by natural drivers are unpredictable and cannot be managed and, therefore, can only be described and studied with reference to past events. In contrast, anthropogenic global change can, by definition, be managed through the modulation of human pressures and is predictable, if with great uncertainties. Hence, I focus here on anthropogenic global change, which I refer hereafter, for simplicity, as global change. Yet, the term anthropogenic global change has not been clearly defined to date. I offer here a definition as:

\section{Anthropogenic Global Change: \\ The global-scale changes resulting from the impact of human activity on the major processes that regulate the function- ing of the Biosphere.}

This definition is akin to that implicit in the analysis of Steffen et al. (2006), which can be inferred from their text as the diversity of new planetary scale forces acting on the Earth System that originate in human activity. In order to avoid spurious semantic discussion, which has cluttered much of the debate on one of the main 
components of global change, climate change, a number of key elements on this definition deserve further clarification. First the requirement for human activity to be involved as a key, albeit not necessarily the sole, driver of processes that operate at the global scale. Hence, this definition excludes, as explained above, changes induced by natural processes alone, such as atmospheric oscillations, solar or astronomical forces and processes, and internal processes, such as volcanic eruptions and earthquakes, which have dominated changes in biosphere processes until the nineteenth century. It also excludes human pressures that do not yet lead to changes at the global scale, such as for instance areas where desalination brines are delivered to the sea, which albeit spreading do not reach global scale. Second, the term change in global change does not refer to the changes in biosphere processes, which are all dynamic and are always changing, but to the fact that it is the nature of these processes themselves that has changed. Indeed, if the term change referred to states rather than processes, this concept would be trivial as its antonym, global constancy, does not exist, rendering the concept of global change a spurious one. Lastly, anthropogenic global change does not presuppose that the changes ought to be negative or adverse, although much of the research effort has focussed on such negative impacts. In principle the concept could also accommodate positive changes that deliver benefits to society. Indeed, as discussed below, some global changes lead to reduced pressure on the ocean and improvements in ocean state.

\section{CAUSES AND OPERATION}

Human activity operates as a motor of global change through the combination of two forces, the growth in human population and the growth in per capita resource use, which product defines the ever-growing increase in resource use by humanity (Figure 1). Human population has continuously expanded since humans developed the capacity to control food production and supply, some 10,000 years ago (Cohen, 1995), with steep acceleration of human population growth already drawing concern at the onset of the industrial resolution (Malthus, 1798). Human population currently exceeds 7200 million people and is forecasted to exceed 9000 million by 2050 (United Nations, 2004). This is within the median of the available estimates (ranging from 7600 to 10,500 million people) for the carrying capacity of planet Earth to support humans (Cohen, 1995). Most of these estimates, however, represent minimum estimates, as they consider the minimum resource requirements of individuals and do not consider that access to limiting resources varies greatly across the planet. The continuous increase in resource use per capita, typically at a 10 -fold increase over the twentieth century, has been possible because of technological developments allowing previously inaccessible resources to be retrieved. Examples include deepsea oil and gas deposits, use of seawater through desalination or the conversion of atmospheric $\mathrm{N}_{2}$ in reactive nitrogen for fertilizer application through the HaberBosch process.

The growing use of resources, such as water, energy, animals and plants used as food, key elements, such as nitrogen and phosphorus, minerals and synthetic chemicals has prompted a suite of changes at the global scale. These global changes include climate change, widespread eutrophication, increased UV radiation resulting from decreased stratospheric ozone levels, land use changes and desertification, loss of biodiversity and a deterioration of air, water, and soil quality (Figure 1). These global changes, in turn, impact society, through a degradation of the environmental underpinning of our life quality, increased food and water insecurity, the

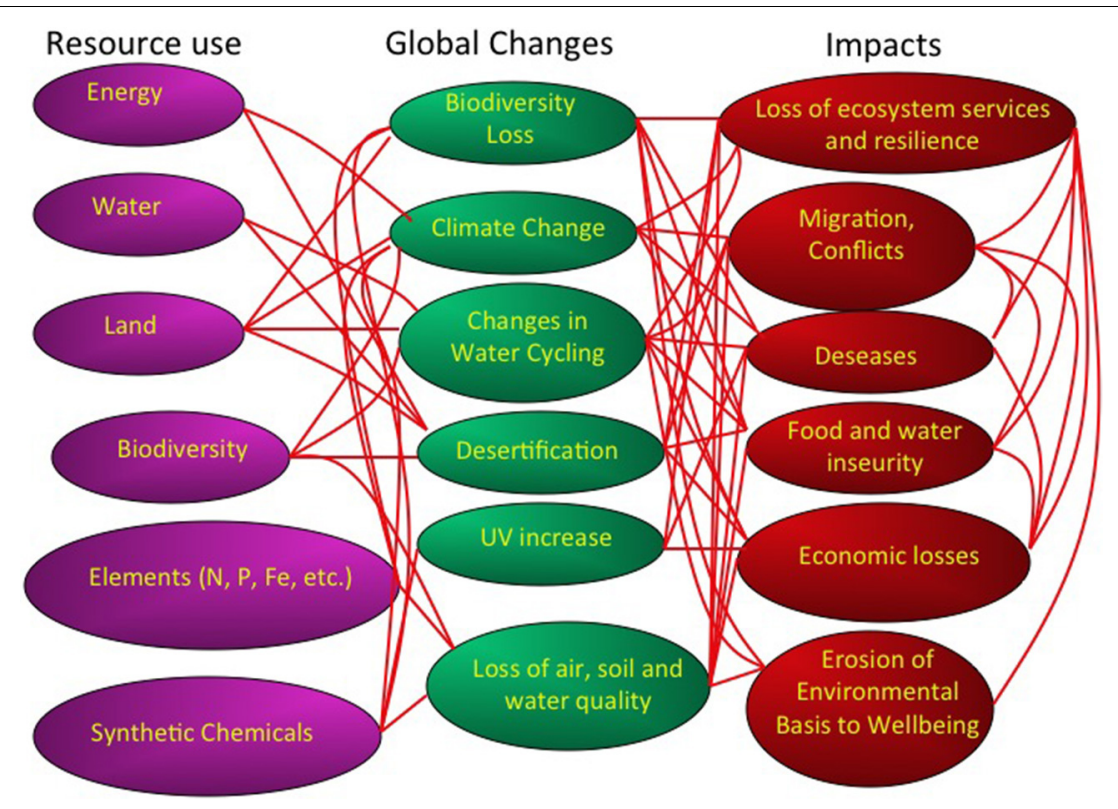

FIGURE 1 | A description of the human pressures, in terms of resource use, global changes, and impacts conforming the global change syndrome. Red lines indicate links between these components. Modified from Duarte et al. (2006). 
outbreak of diseases, as well as conflicts for the control of resources and migratory fluxes of humans to avoid resource deprivation (Figure 1). The growth in resource use, with the associated changes and impacts has reached levels high enough for human activity to dominate multiple global processes, affecting the atmospheric composition and climate, water and elemental cycles and the global distribution of ecosystems on Earth (Figure 1).

Policy makers often address these problems separately, such as portrayed by the UN process, which has separate conventions involving separate mechanisms to address climate change, biodiversity, desertification, synthetic chemicals and the ozone layer. Yet, the drivers of these changes, the changes themselves and their impacts are linked through multiple mechanisms and feed-backs (Figure 1). A reductionist approach, addressing these changes as separate syndromes, is likely to fail. For instance, the role of fossil fuel use as a driver of climate change, led to the belief that promoting biofuels would help mitigate climate change. However, the development of biofuels has acted as an additional driver for tropical deforestation, and increased water, fertilizer and pesticide demand (Fargione et al., 2010) as well as impacts on global food prices. Hence, the set of changes comprising the syndrome of global change is best studied in concert, where their web of interactions and feedbacks can be addressed (Figure 1).

The dominant role of human activity in driving changes in these processes led Crutzen (2002) to propose the term Anthropocene to refer to the present era, where human activity has emerged as a dominant force controlling biospheric processes and driving global change. This capacity is partially driven by technological developments, which have released globally-relevant mechanisms that did not exist in the past. For instance, we could ask the rhetorical questions of what role did chlorofluorcarbon gases, CFC's, or the Haber-Bosch process play in controlling the stratospheric ozone layer and nitrogen fluxes in the geological past. The answer is, of course, none, because CFC's and the Haber-Bosch process were introduced by industrial activities in the second half of the twentieth century. Hence, the statement "The trouble with our time is that the future is no longer what it used to be," which I chose to open this essay, formulated by the french poet Paul Valery in an entirely different context, conveys the core element of the term "change" in Anthropogenic Global Change. The essence of this use of the term "change" is that it does not refer to the climate system or the nitrogen cycle, for example, having experienced changes, as changes have occurred throughout the history of planet Earth, but to the fact that human activity has introduced new control mechanisms, altering in a qualitative manner the way in which key biospheric processes are governed. Likewise, technological developments yet to come may again introduce new regulatory mechanisms in global processes in the future. Indeed, as another poet (Bob Dylan) wrote in 1964 "The Times They are a Changin." "

\section{GLOBAL CHANGE AND THE OCEAN HISTORICAL PERSPECTIVE}

The ocean, as the largest biome on Earth, is a key receptor of human pressures, directly or indirectly. The earliest human pressures on the ocean were exerted through overfishing and hunting of marine animals (Erlandson and Rick, 2010, Figure 2), which was evident already centuries ago. For instance, a three year moratorium on tuna trap fishery was declared in Spain in the eighteenth century by the Duke of Medina Sidonia on the advice of the benedict monk Martín Sarmiento, who determined that widespread declining catches between 1700 and 1730 were due to overfishing (Duarte, 2010). The Steller's Sea Cow (Hydrodamalis gigas), the largest, 8-9 $\mathrm{m}$ in length, mammal species of the order Sirenia was hunted to extinction by Dutch hunters only 28 years after their discovery in the Bering Sea (Anderson, 1995). By the beginning of the nineteenth century, overfishing had become a matter of concern to the extent that whether it was possible and if so whether anything could be done to prevent the exhaustion of fish stocks was debated at the International Fisheries Exhibition in London (1883). There Sir Thomas Huxley ideated the question, "Whether fisheries are exhaustible" and delivered his famous ("last words") statement that: "...I believe that it may be affirmed with confidence that a number of the most important sea fisheries, such as the cod fishery, the herring fishery, and the mackerel fishery, are inexhaustible..."

It is safe to assume that overfishing must have dominated early human impacts on the ocean ecosystem (Erlandson and Rick, 2010), as humans have been gathering sea food for almost 200,000 years (Marean et al., 2007; Ramos et al., 2011; Duarte, 2014) and fishing with hooks for at least 40,000 years (O'Connor et al., 2011). Indeed, impacts from overfishing on the ocean occur probably much later than impacts from human activities on land, as about $20 \%$ of the Earth's temperate woodlands were already under significant human use by 1000 BC

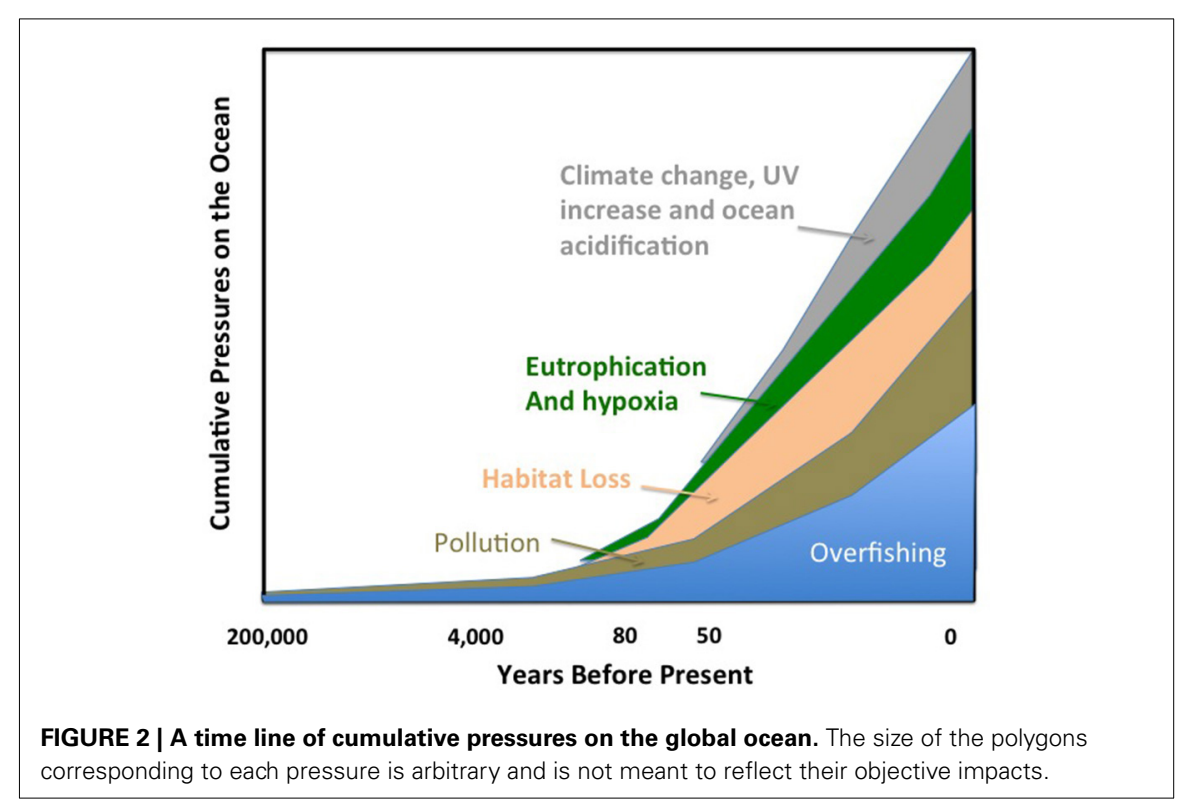


(Ellis et al., 2013). However, large-scale pollution of the ocean by industrial activities dates from about 3640 BP (Figure 2), when emissions from Carthaginian and Roman mining for mercury and silver in Rio Tinto (SW Spain) contributed large heavy metal loads to the N. Atlantic Ocean (Davis et al., 2000). Indeed, lead derived from Carthaginian and Roman mining activities in Rio Tinto has been estimated to account for $70 \%$ of the lead detected in Greenland ice cores dated 600 years BC (Rosman et al., 1997). The increased capacity and volume of metal extraction since the industrial revolution, the mass production of nitrogen-based fertilizers since the industrial application of the Haber-Bosch process and the development of a chemical industry producing hundreds of thousands of different synthetic chemicals for a broad range of applications have led to an anthropogenic chemosphere (Dachs and Méjanelle, 2010). This is reflected in the broad range and global scope of pollutants entering the ocean (Dachs and Méjanelle, 2010). Indeed, the industrial revolution has amplified the capacity of humans to affect the biosphere and the oceans through the massive use of energy. The increased range and power of fishing vessels and associated detection technology has enhanced their capacity to deplete stocks across the world but also to damage the ocean ecosystem. For example, since the 1970s, the oil and gas industry has drilled almost 2000 deep-ocean exploration wells and the depth of openocean fishing has increased by $350 \mathrm{~m}$ per decade since 1950 (Mengerink et al., 2014). Recent analyses showed that reworking of deep-sea sediments by bottom trawling has rendered this an important driver of deep seascape evolution, with an impact comparable to that of plowing on land (Puig et al., 2012). The difference is that rather than such plowing occurring once or twice annually as it does in arable fields, it occurs every day in fishing grounds (Puig et al., 2012). Trawling has profound consequences on the deep-sea ecosystem, decreasing sediment organic matter content and turnover and reducing meiofauna abundance and biodiversity (Pusceddu et al., 2014). We are now starting to realize that trawling destroyed vast extensions of deep coral ecosystems even before we knew these ecosystems existed, as, for instance, along the NE Atlantic coast (e.g., HallSpencer et al., 2005). The use of fossil fuels as a source of energy has prompted one of the major pressures on the ocean, anthropogenic climate change, with its associated impact on ocean chemistry and $\mathrm{pH}$ through the dissolution of anthropogenic $\mathrm{CO}_{2}$ in the ocean (Figures 2, 3). Extraction of these fossil fuels from the ocean, as oil and gas, at increasing depth and their transport across ocean basins has been a source of oil pollution to the ocean for decades (Burgherr, 2007).

The rapid increase in human population since the industrial revolution and their preferential settlement in coastal areas (Small and Cohen, 2004) has led

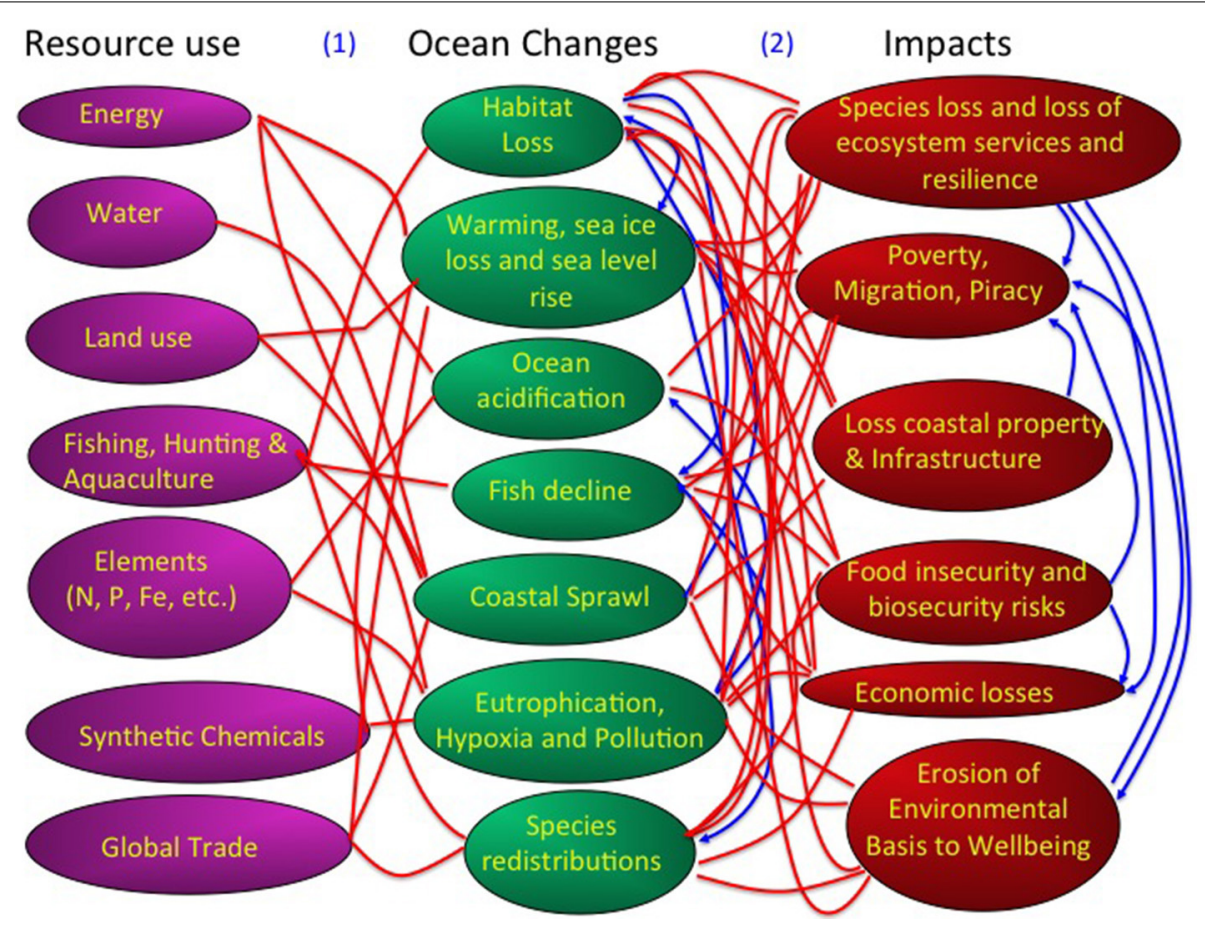

FIGURE 3 |A description of the human pressures, in terms of resource use, oceans changes, and impacts conforming the global change syndrome as affecting the ocean. Red lines indicate links between these components and blue lines denote feedback effects. For a discussion of these links and feedbacks see: (1) Pressures to Ocean Change: (Pauly et al., 1998; Jackson et al., 2001; Hall-Spencer et al., 2005; Orr et al., 2005; Doney et al., 2007, 2009a; Duce et al., 2008; Halpern et al., 2008; Doney, 2010; Gruber, 2011; Kovacs et al., 2011; Duarte et al., 2012a; Jordà et al., 2012; Puig et al., 2012; Boyd, 2013; Kroecker et al., 2013; Poloczanska et al., 2013) (2) Ocean Change to Societal Impacts: (Balmford and Bond, 2005). (Panjabi, 2009; Jentoft et al., 2010; Black et al., 2011; Nicholls et al., 2011; Duarte et al., 2012b; Hinkel et al., 2014). 
to a major physical transformation of the shoreline and a global syndrome of coastal sprawl (Duarte et al., 2012c), associated with the widespread loss of habitats fringing the shoreline, such as mangroves and salt-marshes (Duarte et al., 2008, Figures 2, 3). Together with human settlement in coastal areas, changes in land use in watersheds and river regulation through massive construction of reservoirs over the past 60 years have affected the delivery of materials, from sediments and organic matter to nitrogen, phosphorus, silica, and other elements with an important role in the ocean (e.g., Ittekkot et al., 2000; Walling, 2006). Efficient atmospheric transport also delivers dust, organic carbon, nitrogen and pollutants to the most remote regions of the ocean (e.g., Jurado et al., 2004, 2005, 2008; Doney et al., 2007; Duce et al., 2008), serving as an effective conduit of anthropogenic materials to the ocean.

Whereas the ocean is a rather open environment with high connectivity, human activity has increased connectivity even further, by opening passages connecting ocean basins, such as the Suez and Panama Canals, which act as major vectors for species invasions (e.g., Galil et al., 2007; Galil, 2009), and by transporting water, organisms and propagules across great distance through the global maritime transport. The consequence is a high increase in the introduction of exotic species (e.g., Seebens et al., 2013), some of which behave as invasive species in their new habitats (Ruiz et al., 2000).

The web of changes in the ocean forced by resource use results in a number of impacts affecting the health of the ocean and its capacity to continue to deliver benefits to society (Figure 3). The pathway between drivers, changes and impacts is best represented as a web of global ocean change, as it involves many feedbacks and interactions between these components at multiple levels (Figure 3). When focussing on scales, the range of drivers of change, and therefore the complexity of the matrix of interactions, increase from local to regional and global scales (Boyd and Hutchins, 2012).

\section{ADAPTATION TO GLOBAL CHANGE}

The growth, both in number and strength, of cumulative pressures (Figures 2, 3), are forcing the ocean ecosystem globally at all levels (Figure 3), affecting sea level, ice cover, thermocline structure and mixing, the stability of shorelines, ocean chemistry, ocean productivity and microbial processes, ecosystems structure and stability, biodiversity and biogeographic ranges (e.g., Poloczanska et al., 2013), and uncoupling key processes in the balance of ecosystems, such as the balance between production and respiration in communities (e.g., Duarte et al., 2012a), carbonate formation and dissolution in calcifying organisms (Doney et al., 2009a), recruitment and mortality in populations of marine species (e.g., Jordà et al., 2012), basal and apical species in food webs (Pauly et al., 1998) and even sex ratios in marine poikilotherms (e.g., Depledge and Billinghurst, 1999). These drivers are not only impacting on extant populations but carry long-lasting consequences at evolutionary time scales extending from years to decades (Bell and Collins, 2008). For instance, persistent organic pollutants, most of them synthetic chemicals that did not exist in the environment until a few decades ago, affect all of the evolutionary triggers of organisms, as they may cause mutations, affect life span and the reproductive systems of the organisms and exert strong selection toward resistant strains (e.g., Medina et al., 2007). For instance, marine microalgae in culture collections, which have grown over generations in indoor environments enriched in pollutants, have been shown to have threshold concentrations for mortality for pollutants orders of magnitudes greater than those of the same taxa in the ocean (Echeveste et al., 2010a). Moreover, thresholds of pollutant concentrations for phytoplankton mortality in various ocean regions are higher where pollutant loads are highest, suggesting microevolutionary processes sieving the species and genotypes able to accommodate to high pollutant levels (Echeveste et al., 2010b). Likewise, phytoplankton in the Arctic, an environment supporting very high loads of heavy metals and pollutants of human origin, are extremely resistant to toxic heavy metals, also suggesting this to be the outcome of selective and evolutionary processes leading to adaptation (Echeveste et al., 2014). Increased UV radiation, which played a key role in constraining the early evolution of life in the ocean, has a similar role, as UV radiation damages DNA, may cause mutations and increases mortality (e.g., Häder et al., 2007). Hence, Llabrés et al. (2013) and Agustí et al. (2014) reported marine species in the Southern Hemisphere to be more resistant to UV radiation than those in the Northern Hemisphere. On the basis of these observations, they suggested that selective pressure by UV radiation has sieved genotypes, and possible species, toward more resistant ones in the Southern Hemisphere, where the increase in incident UV levels due to the loss of stratospheric ozone has been much greater for a given latitude than in the Northern Hemisphere (Agustí et al., 2014). These findings suggest that global changes are not only a major driver of extant marine ecosystems, but also of their evolutionary trajectories and, therefore, their future state.

\section{THE FUTURE OCEAN}

It is clear that the ocean is currently changing through the action of a broader set of drivers than those causing changes in paleorecords. Moreover, these drivers keep changing as humans introduce new technologies enabling access to resources not hitherto available, such as forthcoming deep-sea mining (Van Dover et al., 2013; Gross, 2014), floating liquefied natural gas (FLNG, Lee et al., 2012), and, possibly in a more distant future, marine methane hydrates (Sun et al., 2014). Whereas some of the changes are deliberately seeking to lower human pressures on the marine environment, such as the shift from leaded to unleaded fuel, changes in technology propelled by other drivers may have unintended, not necessarily negative, consequences on the ocean. For instance, the advent of digital photography has greatly reduced silver concentrations in the marine environment, an unintended consequence of this technology, as exemplified in up to $80 \%$ reduction in silver levels found in the rhizomes of a Mediterranean seagrass from 1990 to 2005 (Tovar-Sánchez et al., 2010). As a consequence, past ocean states may not be a valid analog to the future ocean, and forecasting how the future ocean will be is a daunting task. Assessing what the future ocean will be like is not just a thrilling academic challenge, because 
current scientific understanding informs decision and policies that albeit taken today may have consequences decades into the future. For instance, most infrastructure projects related to the ocean, such as surge barriers, port constructions, shoreline constructions, or oil and gas projects require operational lifespans of several decades to be cost-effective (Tol et al., 2008). Many organisms that are a target of conservation programs, such as whales, turtles and fish have near-centennial life spans, or even as long as tens of millennia for the protected Mediterranean seagrass Posidonia oceanica, believed to be the most longevous organism on the biosphere (Arnaud-Haond et al., 2012). Hence, the organisms being born today will be subjected to conditions in designated conservation zones very different from those present now. Hence, planning of infrastructure, industry operations, resource management, coastal real state investment, climate change dynamics, risk assessment and conservation policies all demand a capacity to anticipate the dynamics of change and forecast relevant properties of the future ocean.

\section{TRENDS OF GLOBAL OCEAN CHANGE}

Available forecasts point, with some degree of confidence, at a number of trends, some of them involving quantitative brackets on the possible future state of the ocean (Table 1). For instance, by the end of the twenty-first Century the oceans will be warmer, with a reduced ice extent, higher sea level, more acidic and with somewhat lower oxygen levels than at present (Table 1). The ocean will continue to experience a tropicalization, involving an additional poleward expansion of the subtropical gyres with a decline in productivity and a poleward expansion of marine species tracking the migration of the isotherms with warming (Burrows et al., 2011, 2014; Poloczanska et al., 2013), and organisms in both equatorial and polar regions will be compromised by temperature regimes approaching the limits of their thermal capacity (Burrows et al., 2011, 2014). Coastal sprawl, the occupation of coastal areas by human artifacts, will continue to expand with the spread of marine energy and aquaculture parks. Aquaculture will continue to spread with an increase number of domesticated species (Duarte et al., 2007b) and will occupy a larger share, but still a small percent, of the coastal ocean, increasingly extending offshore (Duarte et al., 2009a). Desalination will continue to increase in capacity in an increasing water-limited world and may soon exceed wild fisheries catches in economic value, possibly generating impacts when returning salts, as concentrated brine, to the marine environment. Pumping of deep, cold waters to air condition cities may eventually representing a significant upwelling process, as these waters will be returned near surface. The volume and extent of sea ice will continue to decline in the Arctic Ocean, shifting from a white cold ocean to a darker, warmer ocean, affecting the global albedo and climate. On going changes in the Arctic, in particular, have triggered a number of disruptive changes, including an increase in industrial activities in the Arctic as resources become accessible (Table 1), that together with the rapid changes in the environment represent a case for dangerous climate change (Duarte et al., 2012a).

\section{SOURCES OF UNCERTAINTY}

These forecasts provide trajectories of ocean change, which are particularly robust for physical and biogeochemical properties, which can be explored using coupled biogeochemical global circulation models (Table 1). However, predictions of ecosystem responses remain vague and qualitative for the most part, and are therefore of still limited use. The formulation and adoption of mitigation and adaptation strategies requires forecasts of the changes addressing basic questions, such as when, how much and where, helping to constraint the nature of marine ecosystems in the future ocean. This requires a capacity to provide quantitative forecasts. There are three major sources of uncertainty that converge to render predictions on the future ocean cumbersome. Likely the largest source of uncertainty rests with human drivers, as not only social dynamics and shifts in consumer attitudes are difficult to forecast, but the introduction of new, disruptive technologies are intrinsically unpredictable, and may lead to dramatic departures from predictions based on simple extrapolations of current trajectories.
Natural processes have also the capacity to induce state-changes in the ocean at the global scale, including climatic oscillations, volcanic eruptions, tsunamis and other high-energy events. Often such natural phenomena can trigger changes chained in a domino mode, amplifying their impacts or generating additional impacts. An example of such case would be the accident of the power plan in Fukushima, Japan, as a consequence of a high-energy tsunami. Whereas the impact of the tsunami has been relatively buffered by reconstruction activities, spills of radioisotopes to the marine environment from the nuclear reactors continue to occur three years following the tsunami, with important consequences for the West Pacific marine ecosystem (Garnier-Laplace et al., 2011). A third source of uncertainty is the prevalence of non-linear processes and elements that can lead to abrupt changes in the ocean ecosystem once thresholds of pressures are trespassed (e.g., Andersen et al., 2009; Duarte et al., 2012a,b), departing from the linear, smooth responses that are amenable to prediction and management through modeling approaches.

\section{FACING COMPLEXITY: TIPPING ELEMENTS, THRESHOLDS, POINTS OF NO RETURN}

The notion that changes in ecosystems in response to pressures are smooth, linear and reversible is challenged by widespread evidence that complex systems, composed of multiple interacting elements as most natural systems are, tend to show a non-linear response to pressures where initially smooth, gradual responses to pressures are replaced by an abrupt qualitative state shift once the pressure exceeds a limit, termed a threshold or tipping point (Andersen et al., 2009; Duarte et al., 2009b, 2012a,b). The trajectory of recovery to the original state of the system following reduction of the pressure typically follows a different pathway, such that return to the previous state is only achieved when pressures are relaxed to a much lower level than those causing the critical transition when pressures increased (Figure 4, Duarte et al., 2009b). The reason for such difference in thresholds with increasing or decreasing pressures (Figure 4) is that a state change sets up a new set of buffers that tend to hold 
Table 1 | Qualitative and quantitative forecasts for a future ocean.

\begin{tabular}{|c|c|c|c|}
\hline Component & Trend & Change by 2090 (relative to 1990) & References \\
\hline \multirow[t]{4}{*}{ Physical system } & Warmer ocean & $0.56 \pm 0.71$ to $2.73 \pm 0.7^{\circ} \mathrm{C}$ & Gruber, 2011; Bopp et al., 2013 \\
\hline & Reduced sea ice extent and volume & $\begin{array}{l}\text { Ice-free Arctic Ocean in summer by } \\
2050\end{array}$ & $\begin{array}{l}\text { Wang and Overland, 2012; Berdahl } \\
\text { et al., 2014; Overland et al., } 2014\end{array}$ \\
\hline & Higher mean sea level & 34 to 86 (25 to 123$) \mathrm{cm}^{a}$ & Hinkel et al., 2014 \\
\hline & More stratified ocean & $\begin{array}{l}\text { About } 0.2 \mathrm{Kg} \mathrm{m}^{-3} \text { increase in density } \\
\text { gradient in the upper ocean }\end{array}$ & Gruber, 2011 \\
\hline \multirow[t]{4}{*}{ Biogeochemical system } & Increased $p \mathrm{CO}_{2}$ in surface waters & 421-936 ppm (same as atmospheric) & Bopp et al., 2013 \\
\hline & $\begin{array}{l}\text { Reduced } \mathrm{pH} \text { and saturation state for } \\
\text { carbonate minerals }\end{array}$ & $\begin{array}{l}-0.07 \pm 0.001 \text { to }-0.33 \pm 0.003 \mathrm{pH} \\
\text { units }\end{array}$ & Bopp et al., 2013 \\
\hline & $\begin{array}{l}\text { Reduced oxygen content and } \\
\text { expansion of hypoxic areas }\end{array}$ & $\begin{array}{l}-1.81 \pm 0.31 \text { to }-3.45 \pm 0.44 \% \\
\text { decline in } \mathrm{O}_{2} \text { globally }\end{array}$ & $\begin{array}{l}\text { Keeling et al., 2010; Gruber, 2011; } \\
\text { Bopp et al., } 2013\end{array}$ \\
\hline & Reduced ocean $\mathrm{CO}_{2}$ uptake & Reduced up to $30 \%$ & Gruber, 2011 \\
\hline \multirow[t]{6}{*}{ Human use } & $\begin{array}{l}\text { Increased spatial allocations to } \\
\text { aquaculture }\end{array}$ & Increased 1800 times $^{b}$ & Duarte et al., 2009a \\
\hline & $\begin{array}{l}\text { Increased space allocations to marine } \\
\text { energy }\end{array}$ & $>7 \%$ of world energy use & Esteban and Leary, 2012 \\
\hline & Increased shipping through the Arctic & $\begin{array}{l}\text { Navigation season expanded to } \\
103-120 \text { days per year }\end{array}$ & $\begin{array}{l}\text { Smith and Stephenson, 2013; } \\
\text { Stephenson et al., } 2013\end{array}$ \\
\hline & Increased desalination & $\begin{array}{l}\text { Desalination with renewable energy } \\
\text { able to supply domestic and industrial } \\
\text { water demand within the } 100-\mathrm{km} \\
\text { coastal belt by } 2050\end{array}$ & Sood and Smakhtin, 2014 \\
\hline & Increased coastal population & 3.5 billion people ${ }^{c}$ & United Nations, 2004 \\
\hline & $\begin{array}{l}\text { Increased extraction of mineral } \\
\text { resources from the deep-sea }\end{array}$ & Large increase in development & Lusty and Gunn, 2014 \\
\hline \multirow[t]{7}{*}{ Ecosystem status } & $\begin{array}{l}\text { Reduced biodiversity, particularly that } \\
\text { endemic to polar regions }\end{array}$ & Not quantified & $\begin{array}{l}\text { Pereira et al., 2010; Kovacs et al., } \\
\text { 2011; Wassmann et al., 2011; } \\
\text { Bellard et al., } 2012\end{array}$ \\
\hline & Reduced calcifiers & $\begin{array}{l}\text { Calcification rates possibly reduced by } \\
\text { about } 25 \%\end{array}$ & Kroecker et al., 2013 \\
\hline & $\begin{array}{l}\text { Reduced primary production and } \\
\text { expansion of subtropical gyres }\end{array}$ & $\begin{array}{l}-2.0 \pm 4.1 \% \text { to }-8.6 \pm 7.9 \% \text { decline } \\
\text { in primary production }\end{array}$ & Gruber, 2011; Bopp et al., 2013 \\
\hline & Poleward range expansion of species & $\begin{array}{l}\text { Range shifted poleward by } 720 \mathrm{Km} \text {, on } \\
\text { average }\end{array}$ & $\begin{array}{l}\text { Burrows et al., 2011, 2014; } \\
\text { Poloczanska et al., } 2013\end{array}$ \\
\hline & Continuous decline of coral reefs & $>1 / 3$ of coral reefs degraded & $\begin{array}{l}\text { Pereira et al., 2010; Frieler et al., } \\
2012\end{array}$ \\
\hline & $\begin{array}{l}\text { Reduced habitat available for tropical } \\
\text { pelagic fishes }\end{array}$ & $\begin{array}{l}\text { Estimated } 15 \% \text { habitat loss (in the } \\
\text { Atlantic Ocean) }\end{array}$ & Stramma et al., 2012 \\
\hline & $\begin{array}{l}\text { Increased respiration rates and } \\
\text { reduced net community production }\end{array}$ & Not quantified & $\begin{array}{l}\text { Gruber, 2011; Regaudie-de-Gioux } \\
\text { and Duarte, 2012; }\end{array}$ \\
\hline
\end{tabular}

Uncertainties correspond to different scenarios of future greenhouse gas emissions.

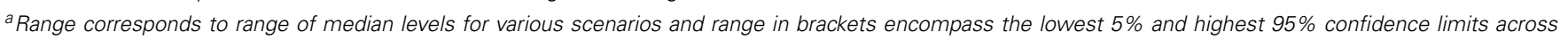
scenarios.

${ }^{b}$ Projecting current $7.5 \%$ growth (Duarte et al., 2009a).

${ }^{c}$ Assumes the current share, 38\% of population within $100 \mathrm{Km}$ from the coast (Small and Cohen 2004), to continue to apply by 2090.

the system in the new state, preventing its return to the original state once pressures are relaxed. The buffers involved have been identified to explain the difficulties to revert coastal ecosystems experiencing hypoxia as a result of eutrophication to normoxic states, where oxygen concentrations satisfy organismal requirements (Conley et al., 2009; Steckbauer et al., 2011). The consequence is non-linearity, reflected in more than one possible system state for a given pressure, and hysteresis, a delay in returning to the prior conditions upon releasing pressure (Figure 4, Duarte et al., 2009b). The elements of the ecosystem that, when perturbed, can trigger such a state change are termed tipping elements (Lenton et al., 2008). 


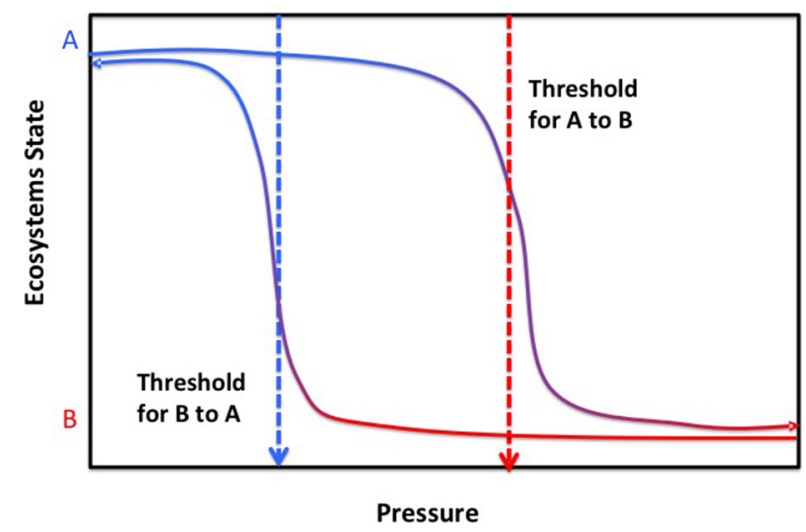

FIGURE 4 | The relationship between pressure and the trajectories of ecosystem states presenting alternative stable states $(A, B)$, indicating the trajectories of change in ecosystem state when pressures increase, with the corresponding thresholds for abrupt change from state $A$ to $B$ with increasing pressure (red dotted arrow), and that for ecosystem state when pressures are relaxed, with the corresponding thresholds for abrupt change from state $B$ to $A$ with decreasing pressure (blue dotted arrow). Examples of thresholds delineating shifts in alternative states in response to pressures in the marine environment are provided in Table 2.

Non-linear responses of ecosystem components to pressures, poorly captured by models typically unable to handle the complexity of non-linear dynamics, represent a major obstacle for the development of reliable forecasts of the future ocean. In addition, we lack a complete inventory of tipping elements in the ocean ecosystems and their corresponding tipping points or thresholds to pressures, so even if models were able to assimilate this complexity we lack the knowledge to guide the process. Hence, identifying tipping elements with their corresponding tipping points or thresholds is a major challenge acting as a bottleneck precluding reliable scenarios of alternative pathways (more formally, bifurcations) to be produced guiding policy and managerial actions from the local ecosystem scale to the global ocean. A number of tools are available to infer thresholds and tipping points from long-term time series of observations or pressure vs. state relationships (Andersen et al., 2009), which ideally should be verified experimentally (e.g., Holding et al., 2013) and/or with independent data sets (e.g., Duarte et al., 2007a). Indeed, it can be argued that knowledge on a number of tipping elements and tipping points in the ocean that can guide, and is being used to guide, forecasts is already available (Table 2). At an extreme, some thresholds may represent points of no return, from which marine ecosystems cannot return to the previous state or do so only at such long time scales as for the change to be irreversible over operationally time scales. For instance, species extinctions, such as the loss of the Great Auk (Pinguinus impennis) in 1844 by hunting and the desire of collectivists and museums to hold specimens (Bengtson, 1984) or that of Steller's cow to hunting (see above) are terminal events as these populations cannot be recovered by relaxing and regulating hunting pressure. Some of the perturbations in the ocean system, such as the acceleration of sea level rise, have also been pressed beyond a point of no return, as this process has a strong momentum and sea level would not return to preindustrial heights any time soon even if returning atmospheric $\mathrm{CO}_{2}$ to preindustrial values was possible (Nicholls et al., 2011). Whereas this is a reversible process, the time scales of hysteresis, of centuries, is so long that the process can be considered irreversible in managerial time scales. Assessing the risks of trespassing points of no return in the tipping elements vulnerable to change is, therefore, most important when managing future change (Duarte et al., 2012a).

Efforts at validating and using thresholds have often showed that thresholds are not universal and are subject to substantial variability. To illustrate this point we could consider the threshold of warming for loss of Arctic sea ice, as the melting point of ice is very well know, at about $-1.0^{\circ} \mathrm{C}$, depending on salinity, it would seem that predicting the trajectory of Arctic sea ice with future warming should be easy, verging on the trivial. A smooth, gradual trend toward a decline in the minimum extent of sea ice in the Arctic has been evident for decades (e.g., Meehl et al., 2007). Indeed, AR4 assessment of the IPCC report, released in 2007, predicted that the minimum extent of sea ice in the Arctic would continue to decline to reach about 2 million $\mathrm{Km}^{2}$, about $1 / 4$ of the extent in 1979 when satellites records were initiated, by the end of the century (Meehl et al., 2007). However, in the summer of 2007, even before the AR4 was approved and the full contents released, an abrupt sea ice melting event took place that brought sea ice well below the boundaries of uncertainty of the IPCC model (Figure 5). This was followed by subsequent minima, the more recent one being an unprecedented melting event in the summer of 2012 that brought the minimum ice extent to the values predicted in 2007 by the IPCC for 2080 (Figure 5). The Arctic Ocean entered a "time machine" that in just 5 years delivered the extent of ice loss anticipated over more than 70 years (Figure 5). Ice loss in the Arctic is indeed a non-linear process, where a tipping point was likely crossed in 2007 (Duarte et al., 2012a) and is globally significant as it perturbs other relevant Earth Tipping Elements located in the Arctic (Lenton et al., 2008; Duarte et al., 2012a,b). The corollary is that prediction remains challenging even for a process that could be thought of as governed by simple thresholds, such as the melting point of sea ice.

\section{CUMULATIVE IMPACTS}

Thresholds in marine systems are dynamic and variable. For instance, some of the variability in threshold oxygen concentrations for marine invertebrates are attributable to differences among taxa (Vaquer-Sunyer and Duarte, 2008), and the effects of warming (Vaquer-Sunyer and Duarte, 2011), and sulfide (VaquerSunyer and Duarte, 2010) in lowering those thresholds. The reasons are evolutionary and phylogenetic differences in the capacity of organisms to tolerate multiple pressures and the fact that organisms do not respond to single stressors 
Table 2 | Examples of tipping elements with their corresponding thresholds and tipping points to pressures in the marine environment.

\begin{tabular}{|c|c|c|c|}
\hline Tipping element & Pressure & Threshold or tipping point & References \\
\hline Biocalcification & $\begin{array}{l}\text { Ocean } \\
\text { acidification }\end{array}$ & $\begin{array}{l}\text { Saturation states for aragonite or calcite } \\
(\Omega<1) \\
\text { Responses differ greatly among species }\end{array}$ & $\begin{array}{l}\text { Orr et al., } 2005 \\
\text { Ries et al., 2009; Hendriks et al., 2010; McCulloch } \\
\text { et al., 2012; Kroecker et al., } 2013\end{array}$ \\
\hline Seagrass loss & $\begin{array}{l}\text { Reduced light } \\
\text { penetration }\end{array}$ & $\begin{array}{l}\text { Underwater irradiance }>11 \% \text { of surface } \\
\text { value }\end{array}$ & Duarte, 1991; Duarte et al., 2007a \\
\hline Invertebrate mortality & Hypoxia & $\begin{array}{l}\text { Mean oxygen concentration for } \\
\mathrm{LC}_{50}=2.05 \mathrm{mg} \mathrm{O}_{2} \mathrm{~L}^{-1}\end{array}$ & Vaquer-Sunyer and Duarte, 2008 \\
\hline Coral loss & Warming & $>2^{\circ} \mathrm{C}$ over 1990's & Hughes et al., 2003 \\
\hline $\begin{array}{l}\text { Net community metabolism } \\
\text { (Arctic plankton) }\end{array}$ & Warming & $\begin{array}{l}\text { Shifting from positive to negative at } \\
>5-5.4^{\circ} \mathrm{C}\end{array}$ & Holding et al., 2013 \\
\hline $\begin{array}{l}\text { Plankton community metabolism } \\
\text { (non-polar ocean) }\end{array}$ & Warming & Shifting from positive to negative at $>21^{\circ} \mathrm{C}$ & Regaudie-de-Gioux and Duarte, 2012 \\
\hline Calanus glacialis mortality & Warming & Metabolic collapse at $>5^{\circ} \mathrm{C}$ & Alcaraz et al., 2013 \\
\hline \multirow[t]{2}{*}{ Phytoplankton mortality } & $\mathrm{PAHs}$ & $\begin{array}{l}\text { Depending on taxa and complexity of } \\
\text { mixture }\end{array}$ & Echeveste et al., 2010a,b \\
\hline & Heavy metals & $\begin{array}{l}\text { Depending on community and specific } \\
\text { element }\end{array}$ & Echeveste et al., 2014 \\
\hline
\end{tabular}

independently, but integrate responses to the multiple stresses they are facing (Adams, 2005). That the response to multiple stressors may not be additive, but also be synergistic or antagonistic (Crain et al., 2008; Hofmann and Todgham, 2010) adds further complexity to forecasting the future ocean (Boyd and Hutchins, 2012), as many pressures operate simultaneously (Figure 2). Hence, considerable research effort is already directed and will be directed toward understanding responses of marine systems to multiple, cumulative pressures, which is widely acknowledged as a top research priority for marine scientists (Boyd and Hutchins, 2012; Boyd, 2013; Rudd, 2014). A robust pathway to inference is necessary, involving multiples lines of evidence to assign causality. In particular the application of a modified set of Koch's postulates has been proposed as a framework to establish a robust set of causal criteria when examining multiple stresses (Adams, 2005).

\section{ACCLIMATION AND ADAPTATION}

Further complexities in predicting responses of the ocean ecosystem to different pressures arise from the intrinsic capacity of organisms to acclimate and adapt to stress through a series of processes, including physiological mechanisms (Hofmann and Todgham, 2010), microevolution and ecosystem-level interactions (Boyd and Hutchins, 2012). For instance, the widely held assumption, based solely on chemical principles, that corrosive waters to carbonate minerals (i.e., saturation states, $\Omega<1$ ), should preclude biocalcification processes has been challenged on the face of the existence of multiple processes, at the level of ecosystem, individual or cellular, that allow organisms to calcify at much lower $\Omega$ values, by compartmentalizing the site for this process or up-regulating $\mathrm{pH}$ and ion concentration through pump mechanisms, requiring energy (McCulloch et al., 2012; Hendriks et al., 2014a). Likewise, the importance of microevolutionary processes in shifting thresholds of various stressors is becoming apparent, questioning the power of experimental evidence on thresholds of performance of organisms to slowly developing stresses, such as warming (Visser, 2008) and ocean acidification (e.g., Lohbeck et al., 2012; Schlüter et al., 2014; Sunday et al., 2014), derived today to predict future responses. Global change presents a clear, immediate and urgent challenge for evolutionary biology to demonstrate and predict the potential of microevolutionary processes to lead to adaptation to the various stressors in operation (Bell and Collins, 2008).

Experimental analyses of responses to global change forces typically confine the organisms, sometimes as single species of simplified assemblages, in experimental units and in doing so remove ecosystemlevel interactions that may modulate responses. For instance, the photosynthetic activity of seagrass, raising $\mathrm{pH}$, can 


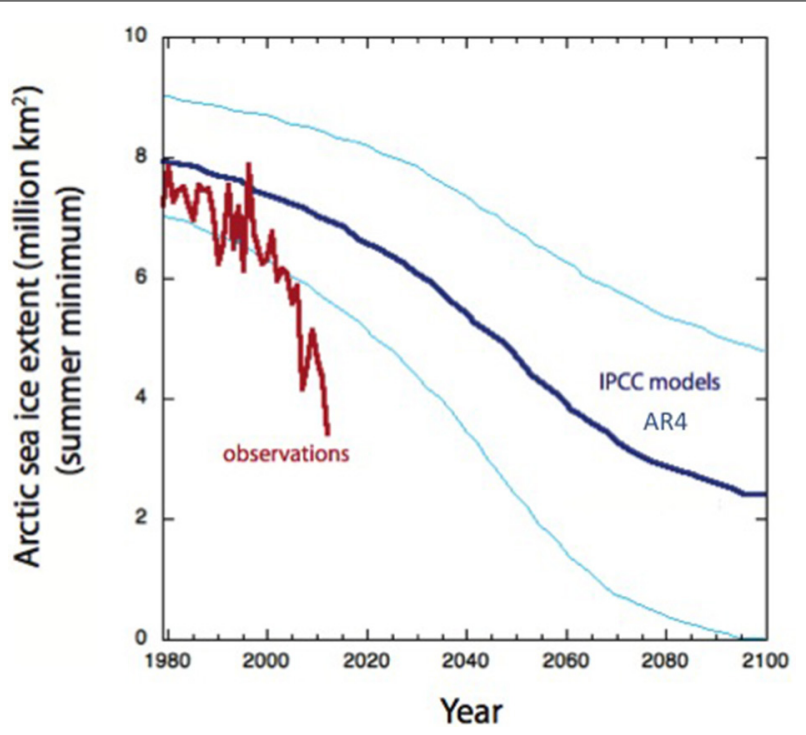

FIGURE 5 | The predicted (thick blue line mean and thin blue lines uncertainty bands, based on AR4 IPCC models, Meehl et al., 2007) and observed (red line) annual minimum sea ice extent (1979-2012). Observed ice extent from Fetterer et al. (2014) (2002, updated 2009, Accessed August 5, 2014).

help mitigate the impacts of ocean acidification (Hendriks et al., 2014b) or may provide shading from exposure to otherwise elevate UV radiation, providing refugia to vulnerable species. The duration of the experiments is typically of a few days, as long-term experiments are more vulnerable to artifacts that may confound the results (Duarte et al., 1997b). Hence, although some experimental approaches allow for acclimation, e.g., usually 10 generations of lab cultured phytoplankton, few have conducted sufficiently long experiments as to account for the role of adaptation. Bell and Collins (2008) propose a useful framework to assess the likelihood of adaptation to stresses based on the comparison of the rate of change in the stress of interest relative to the species generation time as well as the potential of the stress to supply mutations to the population on which selective processes could operate.

\section{MODELS FORECAST AND VALIDATION}

Integrating responses to predict the effect of global change on marine ecosystems is a major challenge, but not a hopeless one if a parsimonious approach to this task is adopted. A first step involves building a conceptual model of the process that is to be forecasted, and challenging this model to isolate the most parsimonious set of essential components and processes required to formulate an informed forecast. A second step involves assessing the robustness of available knowledge to parametrize the relations between forcing functions, processes and components to identify critical unknowns and uncertainties. These must then be strengthened through a combination of efforts to achieve mechanistic understanding, derived from process studies and controlled experiments, validated by opportunistically challenging the capacity of this understanding to formulate testable predictions against data available from longterm series and unintended experiments.

The models can then be used to explore possible outcomes for a future ocean, either globally or regionally. Uncertainties in future forcings and responses can be addressed by exploring a range of possible outcomes or pathways toward future ocean states. This is conventionally done in climate change science through the use of scenarios involving different assumptions on the future behavior of anthropogenic greenhouse gas emissions (Moss et al., 2010), the element involving the highest uncertainty in climate models. However, scenarios can also be used to model responses where considerable uncertainty exists. These include, for instance, feedback between forcing and responses, such as the possible effect of increased $\mathrm{CO}_{2}$ on photosynthetic rates of marine primary producers; interactions between multiple stresses or the capacity for adaptive processes to alter the thresholds and responses to stresses. I believe, therefore, that approaches to forecast the future ocean should not lead to a unique projection of the future ocean, but a broad diversity of alternative future oceans, which may cluster onto a parsimonious, manageable, set of outcomes.

The conventional approach to build confidence on a model will be to compare the predictions against observations. However, it is not reasonable to expect that we wait until 2050 or later to assess if current models are correct, as we are building these models precisely to support decisions that must be taken to address pressing environmental issues today. A conventional approach to bypass this limitation is assessing model skill in hind casting past dynamics (e.g., Doney et al., 2009b), which then provides confidence on their future performance. This involves, however, considerable risk, as the various pressures are moving into domains that exceed those encountered in the past (Table 1). Hence, model skill at hind casting past dynamics does not provide a reliable proxy for model skill at forecasting future states where key forcings shift onto ranges not encountered in the recent past (e.g., atmospheric $\mathrm{CO}_{2}$ partial pressure, global temperature, sea level). An additional approach, known as multi-model ensemble combination (Collins, 2007), developed to model meteorology and climate, involves the use of the spread in the output of of number of models as a proxy for uncertainty in future conditions. This, however, would be correct if the models would be entirely independent, but most models share a large fraction of their core parametrization and structure, so their output cannot be considered truly independent. Hence, model ensembles do not provide a reliable estimate of uncertainty although they are helpful in exploring the consequences of the different assumptions and parametrizations used in the models (i.e., sensitivity analyses). Moreover, even if we were to wait until 2050 to validate the models, this would still be insufficient. The reason for this is that the "experiment," i.e., the changes leading to the future ocean, 
cannot be replicated, so we have a single set to validate the model. This represents a problem of singularity or uniqueness (Barnett, 1984), as there is only one planet and independent replication, as we would do in addressing any other problem in science, is not possible.

Provided these limitations, a pathway to improve our confidence in the predictions of future ocean states derived from models involves a key role for the identification of testable hypothesis that address core elements of the model. This pathway requires inspecting the model structure either formally, using for instance sensitivity analysis, or informally by deconstructing the model into its fundamental components, to identify a set of finite drivers of the forecasts. Indeed, model deconstruction approaches have shown that ecosystem models can often be simplified to much smaller versions of the full model while retaining their predictive power (Håkanson, 1995). Identification of such parsimonious sets of core components carrying the weight of the model should be followed with the formulation of testable hypothesis challenging the knowledge underpinning each of the essential model elements. These hypotheses should then be tested thoroughly. Where these tests fail to reject the hypothesis, the confidence on the particular essential element of the model underpinned by that particular hypothesis is enhanced. In a nutshell, the key hypothesis and assumptions conforming the core of a model of the future ocean should be challenged following strong inferential approaches (Platt, 1964).

Validating models and key hypotheses and assumptions requires a coordinated observational program fit-for-purpose. This program should observe the variables necessary to represent the pressures and the responses and committed to long-term continuity. For instance, the long-term (i.e., decades) observations on $\mathrm{pH}$ at long-term stations ALOHA, off Hawaii, and BATS, off Bermuda, have provided a fundamental underpinning for the predicted ocean acidification with increasing atmospheric $\mathrm{CO}_{2}$ (e.g., Doney et al., 2009a). Ocean acidification has been proposed as one of the planetary boundaries defining the sustainable operation space for humanity (Rockström et al.,
2009). Indeed, the coordinated program of observation should monitor the ocean ecosystem against known thresholds for abrupt changes in response to global change (e.g., Table 2). Observation programs aimed at detecting the impacts of anthropogenic global change on the ocean should be designed considering a priori expectations so that they have the power to formally test these expectations, thereby allowing robust attribution of the changes to pressures (O'Connor et al., 2014). Moreover, this program may include direct observations as well as coordinated experiments that improve the capacity to test hypothesis and understand the variability in response to pressures across the ocean. An opportunity for the development of such coordinated ocean observation program is provided by the forthcoming development of biogeochemical and biological components for the Global Ocean Observing System, successfully implemented to observe ocean physics thus far.

\section{BLACK SWANS AND THE UNEXPECTED}

Whatever thorough our models might be, they are always open to interference by unforeseeable events, whether this be "unknown unknowns" (Wintle et al., 2010) or the unexpected (Polasky et al., 2011). Facing unknown unknowns requires a critical and skeptic approach to current understanding involving a systematic and recurrent analysis of gaps and flaws, while addressing the unexpected requires widening the frame of scenarios explored to incorporate those with even very low a priori likelihood (Polasky et al., 2011). Such "black swans," a metaphor for the unexpected in philosophy of science (Macdonald-Ross, 1979), are unlikely but cannot be discarded precisely because we have a single ocean. How unlikely an event maybe is irrelevant if it is that precisely event that happens to occur. "Black Swans" resulting in pathways toward unanticipated future oceans may derive, for instance, from disruptive technologies changing, for the positive or the negative, human pressures on the ocean. Examples are the impacts on biodiversity and the stratospheric ozone layer of DDT's or CFC's, respectively, until their negative impacts were realized and these compounds regulated (Solomon, 2004).
"Black Swans" may also result from "perfect storms," where natural events with low probability of occurrence add to human forcing to generate unexpected, potentially catastrophic events. Examples include the role of prior mangrove logging on rising the loss of human lives during the Indian ocean tsunami of December 2004 (Danielsen et al., 2005) and the major accident caused by the impact of a tsunami on the Fukushima power-plan located in an earthquake-prone area (Garnier-Laplace et al., 2011).

The approach the scientific community concerned with forecasting alternative future oceans should implement to deal with unknown unknowns and black swans can be inspired to that recommended for states and organizations to deal with the unexpected (Henderson, 1997). The scientific community must scan and analyze new and unlikely, but plausible, developments, formulate appropriate strategic plans to cope with such events and implement these through an adaptive management process (Costanza et al., 1998). Scanning the unexpected requires a more open, less dogmatic approach to the free discussion of ideas than currently practiced. This is regulated by the peer review system, which, as currently practiced, operates to suppress, rather than promote, new ideas and thoughts that may be perceived to challenge established paradigms. I have personally been charged of poor professional ethics by anonymous reviewers when questioning, based on what I considered were legitimate arguments, some accepted paradigms or challenging views that "the scientific community" embraces. Peer pressure to commit to establish paradigms deters from progress in science but involves risks when the paradigms refer to future states of the planet carrying huge consequences for society.

\section{HORIZON SCANNING AND OPEN DEBATES}

Suppressing debate is detrimental to the progress of a science program, such as that concerned with global change and the future ocean, plagued with so many uncertainties. New philosophies to the peer review process are needed, such as those implemented in Frontiers in journals where the review process focusses on working constructively with the authors 
to certify the accuracy and validity of articles, not on evaluating their significance (http://www.frontiersin.org/about/ reviewsystem). Such editorial policies are required to ensure that new ideas and concepts are not rejected simply because they do not conform with established paradigms or a particular world view, but only because they are objectively flawed. I whole heartedly concur with my friend Cole (2013) in his statement that "there is nothing better for science than a good, loud, public disagreement" and we need, therefore, forums for such disagreements to be aired and discussed. Indeed, Frontiers in and other new forums, such as Research Gate, allow for post-publication review and discussion where the merits of the ideas can be further debated. This is, however, useless if dissenting views are suppressed from the literature altogether. Publication bias, resulting from either suppressing ideas that do not conform with established paradigms or from rejecting good research simply because it reports negative results, is a major avenue for black swans to deliver their potentially unpleasant surprises, rendering accepted ensembles of possible future ocean states null and void. Indeed, a number of maladies, including miscitation or selective citation, publication and research bias, confirmatory research among other issues, have been suggested to perpetuate biased views on problems affecting the ocean in the literature (Duarte et al., in press).

\section{COMMUNICATING OCEAN CHANGE, UNCERTAINTY AND THE ROLE FOR SKEPTICISM}

The accumulation of pressures and syndromes of concern on the environment, and the ocean in particular, has conformed the view that the ocean is on a trajectory to collapse (Duarte et al., in press). For instance, Jackson et al. (2001), stated that "Overfishing precedes all other pervasive human disturbance to coastal ecosystems, including pollution, degradation of water quality, and anthropogenic climate change. The litany of changes includes increased sedimentation and turbidity; enhanced episodes of hypoxia or anoxia; loss of seagrasses and dominant suspension feeders, with a general loss of oyster reef habitat; shifts from ecosystems once dominated by benthic primary production to those dominated by planktonic primary production; eutrophication and enhanced microbial production; and higher frequency and duration of nuisance algal and toxic dinoflagellate blooms, outbreaks of jellyfish, and fish kills" (Jackson et al., 2001). Such statements are turned into blown out headlines by the mass media, as they align with the "New Environmental Paradigm" focussed on the insults to the environment associated with sustained growth in human appropriation of resources (Dunlap and Van Liere, 2008). While many of those changes are indeed well documented and disturbing, some of the alleged syndromes portraying an ocean at the brink of collapse are not as strongly supported (Duarte et al., in press). For instance, evidence that jellyfish are increasing globally is weak at best, as analyses suggests that jellyfish may be, instead, experiencing globally synchronous long-period oscillations (Condon et al., 2013). A recent assessment of the mass of plastic litter floating in the global open ocean has arrived to $1 \%$ of the amount expected (Cózar et al., 2014). Additionally, overfishing may not be as widespread or severe as often portrayed (Hilborn, 2006). Assessments of public perception of problems affecting the ocean have revealed that the public has a distorted perception of the magnitude and immediacy of some of the changes, pointing at flaws in communicating research findings to the public (Gelcich et al., 2014).

There is a need to remain skeptical and avoid a tendency toward embracing new ocean syndromes as critical problems compromising the ocean before a critical assessment of the empirical evidence provides strong support (Duarte et al., in press). Such skepticism must be exerted in an organized manner (Merton's, 1973), i.e., from within the boundaries of the scientific method and through the mechanisms for self-regulation the scientific community has. For instance, Pandolfi et al. (2011) examined the future of corals in a warmer and acidifying ocean to conclude that emerging evidence for variability in coral responses and potential rates support an scenario, alternative to that of the imminent disappearance of modern reefs globally (Tables 1,2 ), in which reef degradation occurs with greater temporal and spatial heterogeneity than current projections suggest. Such alternative scenario also deserves close attention. Careful, skeptical assessments of the syndromes of the ocean in response to human pressures is essential to promote discussion conducive to improved understanding and to identify key problems that require urgent policy actions to avoid further ocean deterioration (Duarte et al., in press).

Likewise, we should strive at communicating our results and findings to the public in ways that would not cause unnecessary alarm, avoiding falling hostage, as the alleged sources of inflated headlines, to the competition of media for the public attention. Whereas we should consider "black swans" and "perfect storms," these are, by definition unexpected events and need not be presented to the public as unavoidable futures. Indeed, effective communication with policy makers, the public and the media, require that scientists involved in examining global change and the future ocean forge strong partnerships with professional communicators psychologists, sociologists, and other social scientists, to frame our findings in effective ways (Groffman et al., 2010) and foster hope and action rather than denial or despair (Sterman, 2008). We must change the current narrative of an ocean plagued with global pressures growing in severity and number, as it depicts a problem of insurmountable proportions conducive to an ocean broken beyond repair (Duarte et al., in press). Where possible our messages should be accompanied by information on actions, starting from those that can be taken at the level of the individual, to address the problem and the benefits expected from a healthy ocean.

Lastly, policy makers, the public and the scientific community should accept change as a prerequisite to manage it. Policy makers and the public imagination often set the return to past baseline conditions as targets of public policies. Such wish to return to a Neverland, a land where everything remains perpetually unchanged, is an unlikely goal in a world in constant change, even in the absence of anthropogenic pressures (Duarte et al., 2009b), and failure to return to such baselines often turns into frustration and a reluctance of policy makers to embrace further measures to improve ocean health. 
Managing ocean change requires that we first formulate this as a tractable problem, sorting the multiple pressures according to the magnitude and immediacy of the impacts, their reversibility, and the options available to mitigate and adapt to them locally, regionally or globally. Close cooperation between scientists, managers and policy makers may also help to progress in our capacity to manage ocean problems adaptively, where uncertainties and unknowns are addressed through a learning by doing approach (Jentoft, 2007).

The future ocean will be, no doubt, different in many ways from that we enjoy today, indeed no longer what it used to be. Where our goals, those of policy makers, the public and scientists, should converge is in a commitment to guide this change through the pathway conducive to the best possible future ocean, a healthy ocean with vibrant biology and ecosystems that continue to support our well being. Our job within that social contract, and the mission of the section on Global Change in the Future Ocean where this article is published, is to provide guidance, based on the best possible science, as to how to set a trajectory to meet such pathway and what does it take to remain on it.

\section{ACKNOWLEDGMENTS}

This is a contribution to the Malaspina 2010 Expedition and the ESTRESX projects, funded by the Spanish Ministry of Economy and Innovation (CSD200800077 and CTM2012-32603, respectively). I thank Philip Boyd and R. W. Fulweiler for helpful critical comments.

\section{REFERENCES}

Adams, S. M. (2005). Assessing cause and effect of multiple stressors on marine systems. Mar. Pollut. Bull. 51, 649-657. doi: 10.1016/j.marpolbul.2004.11.040

Agustí, S., Llabrés, M., Carreja, B., Fernández, M., and Duarte, C. M. (2014). Contrasting sensitivity of marine biota to UV-B radiation between Southern and Northern hemispheres. Estuar. Coasts. doi: 10.1007/s12237-014-9790-9

Alcaraz, M., Felipe, J., Grote, U., Arashkevich, E., and Nikishina, A. (2013). Life in a warming ocean: thermal thresholds and metabolic balance of Arctic zooplankton. J. Plankton Res. 36, 3-10 doi: $10.1093 /$ plankt/fbt111

Andersen, T., Carstensen, J., Hernandez-Garcia, E., and Duarte, C. M. (2009). Ecological thresholds and regime shifts: approaches to identification. Trends Ecol. Evol. 24, 49-57. doi: 10.1016/j.tree.2008.07.014
Anderson, P. K. (1995). Competition, predation, and the evolution and extinction of Steller's sea cow, Hydrodamalis gigas. Mar. Mamm. Sci. 11, 391-394. doi: 10.1111/j.1748-7692.1995.tb00294.x

Arnaud-Haond, S., Duarte, C. M., Diaz-Almela, E., Marbà, N., Sintes, T., and Serrão, E. A. (2012). Implications of extreme life span in clonal organisms: millenary clones in meadows of the threatened seagrass Posidonia oceanica. PLoS ONE, 7:e30454. doi: 10.1371/journal.pone.0030454

Balmford, A., and Bond, W. (2005). Trends in the state of nature and their implications for human well-being. Ecol. Lett. 8, 1218-1234. doi: 10.1111/j.1461-0248.2005.00814.x

Barnett, T. P. (1984). The estimation of "global" sea level change: a problem of uniqueness. J. Geophys. Res. Oceans 89, 7980-7988. doi: 10.1029/JC089iC05p07980

Bell, G., and Collins, S. (2008). Adaptation, extinction and global change. Evol. Appl. 1, 3-16. doi: 10.1111/j.1752-4571.2007.00011.x

Bellard, C., Bertelsmeier, C., Leadley, P., Thuiller, W., and Courchamp, F. (2012). Impacts of climate change on the future of biodiversity. Ecol. Lett. 15, 365-377. doi: 10.1111/j.1461-0248.2011.01736.x

Bengtson, S. A. (1984). The great auk (Pinguinus impennis): anecotal evidence and conjectures. Auk 101, 1-12.

Berdahl, M., Robock, A., Ji, D., Moore, J. C., Jones, A., Kravitz, B., et al. (2014). Arctic cryosphere response in the geoengineering model intercomparison Project G3 and G4 scenarios. J. Geophys. Res. Atmos. 119, 1308-1321. doi: 10.1002/2013JD020627

Black, R., Adger, W. N., Arnell, N. W., Dercon, S., Geddes, A., and Thomas, D. (2011). The effect of environmental change on human migration. Glob. Environ. Change 21, S3-S11. doi: 10.1016/j.gloenvcha.2011.10.001

Bopp, L., Resplandy, L., Orr, J. C., Doney, S. C., Dunne, J. P., Gehlen, M., et al. (2013). Multiple stressors of ocean ecosystems in the 21st century: projections with CMIP5 models. Biogeoscience 10, 6225-6245. doi: 10.5194/bg-10-6225-2013

Boyd, P. W. (2013). Framing biological responses to a changing ocean. Nat. Clim. Change 3, 530-533. doi: 10.1038/nclimate1881

Boyd, P. W., and Hutchins, D. A. (2012). Understanding the responses of ocean biota to a complex matrix of cumulative anthropogenic change. Mar. Ecol. Prog. Ser. 470, 125-135. doi: 10.3354/meps 10121

Burgherr, P. (2007). In-depth analysis of accidental oil spills from tankers in the context of global spill trends from all sources. J. Hazard. Mater. 140, 245-256. doi: 10.1016/j.jhazmat.2006.07.030

Burrows, M. T., Schoeman, D. S., Buckley, L. B., Moore, P. J., Poloczanska, E. S., Brander, K. M., et al. (2011). The pace of shifting climate in marine and terrestrial ecosystems. Science 334, 652-655. doi: $10.1126 /$ science. 1210288

Burrows, M. T., Schoeman, D. S., Richardson, A. J., García Molinos, J., Hoffmann, A., Buckley, L. B., et al. (2014). Geographical limits to species-range shifts are suggested by climate velocity. Nature 507, 492-495. doi: 10.1038/nature12976

Cohen, J. E. (1995). How many people can the earth support? Sciences 35, 18-23. doi: 10.1002/j.23261951.1995.tb03209.x
Cole, J. J. (2013). "Freshwater ecosystems and the carbon cycle," in Excellence in Ecology, Vol. 18, ed O. Kinne (Oldendorf/Luhe: International Ecology Institute), 146.

Collins, M. (2007). Ensembles and probabilities: a new era in the prediction of climate change. Philos. Trans. R. Soc. A Math. Phys. Eng. Sci. 365, 1957-1970. doi: 10.1098/rsta.2007.2068

Condon, R. H., Duarte, C. M., Pitt, K. A., Robinson, K. L., Lucas, C. H., Sutherland, K. L., et al. (2013). Recurrent jellyfish blooms are a consequence of global oscillations. Proc. Natl. Acad. Sci. U.S.A. 110, 1000-1005. doi: 10.1073/pnas.1210920110

Conley, D. J., Carstensen, J., Vaquer-Sunyer, R., and Duarte, C. M. (2009). Ecosystem thresholds with hypoxia. Hydrobiologia 629, 21-29. doi: 10.1007/s10750-009-9764-2

Costanza, R., Andrade, F., Antunes, P., van den Belt, M., Boersma, D., Boesch, D. F., et al. (1998). Principles for sustainable governance of the oceans. Science 281, 198-199. doi: 10.1126/science.281.5374.198

Cózar, A., Echevarría, F., González-Gordillo, J. I., Irigoien, X., Úbeda, B., Hernández-León, S., et al. (2014). Plastic debris in the open ocean. Proc. Natl. Acad. Sci. U.S.A. 111, 10239-10244. doi: 10.1073/pnas.1314705111

Crain, C. M., Kroeker, K., and Halpern, B. S. (2008). Interactive and cumulative effects of multiple human stressors in marine systems. Ecol. Lett. 11, 1304-1315. doi: 10.1111/j.14610248.2008.01253.x

Crutzen, P. J. (2002). The "anthropocene." J. Phys. IV 12, 1-5. doi: 10.1051/jp4:20020447

Dachs, J., and Méjanelle, L. (2010). Organic pollutants in coastal waters, sediments, and biota: a relevant driver for ecosystems during the anthropocene? Estuar. Coasts 33, 1-14. doi: 10.1007/s12237-0099255-8

Danielsen, F., Sørensen, M. K., Olwig, M. F., Selvam, V., Parish, F., Burgess, N. D., et al. (2005) The Asian tsunami: a protective role for coastal vegetation. Science 310:643. doi: 10.1126/science. 1118387

Davis, R. A. Jr., Welty, A. T., Borrego, J., Morales, J. A., Pendon, J. G., and Ryan, J. G. (2000). Rio Tinto estuary (Spain): 5000 years of pollution. Environ. Geol. 39, 1107-1116. doi: 10.1007/s0025499 00096

Depledge, M. H., and Billinghurst, Z. (1999). Ecological significance of endocrine disruption in marine invertebrates. Mar. Pollut. Bull. 39, 32-38. doi: 10.1016/S0025-326X(99)00115-0

Doney, S. C. (2010). The growing human footprint on coastal and open-ocean biogeochemistry. Science 328, 1512-1516. doi: 10.1126/science. 1185198

Doney, S. C., Fabry, V. J., Feely, R. A., and Kleypas, J. A. (2009a). Ocean acidification: the other $\mathrm{CO}_{2}$ problem. Annu. Rev. Mar. Sci. 1, 169-192. doi: 10.1146/annurev.marine.010908.163834

Doney, S. C., Lima, I., Moore, J. K., Lindsay, K., Behrenfeld, M. J., Westberry, T. K., et al. (2009b). Skill metrics for confronting global upper ocean ecosystem-biogeochemistry models against field and remote sensing data. J. Mar. Syst. 76, 95-112. doi: 10.1016/j.jmarsys.2008.05.015

Doney, S. C., Mahowald, N., Lima, I., Feely, R. A., Mackenzie, F. T., Lamarque, J. F., et al. (2007). Impact of anthropogenic atmospheric 
nitrogen and sulfur deposition on ocean acidification and the inorganic carbon system. Proc. Natl. Acad. Sci. U.S.A. 104, 14580-14585. doi: 10.1073/pnas.0702218104

Duarte, C. M. (1991). Seagrass depth limits. Aquat. Bot. 40, 363-377. doi: 10.1016/0304-3770(91)90081-F

Duarte, C. M. (2010). Océano: el secreto del planeta Tierra, Vol. 13. Madrid: Editorial CSIC-CSIC Press.

Duarte, C. M. (2014). Red ochre and shells: clues to human evolution. Trends Ecol. Evol. 10, 560-565. doi: 10.1016/j.tree.2014.08.002

Duarte, C. M., Agustí, S., Wassmann, P., Arrieta, J. M., Alcaraz, M., Coello, A., et al. (2012b). Tipping elements in the Arctic marine ecosystem. Ambio 41, 44-55. doi: 10.1007/s13280-011-0224-7

Duarte, C. M., Alonso, S., Benito, G., Dachs, J., Montes, C., Pardo, M., et al. (2006). "Cambio global: impacto de la actividad humana sobre el sistema tierra," in Colección Divulgación, CSIC (Madrid), 187

Duarte, C. M., Conley, D. J., Carstensen, J., and Sánchez-Camacho, M. (2009b). Return to Neverland: shifting baselines affect eutrophication restoration targets. Estuar. Coasts 32, 29-36. doi: 10.1007/s12237-008-9111-2

Duarte, C. M., Dennison, W. C., Orth, R. J., and Carruthers, T. J. (2008). The charisma of coastal ecosystems: addressing the imbalance. Estuar. Coasts 31, 233-238. doi: 10.1007/s12237-0089038-7

Duarte, C. M., Fulweiler, R. W., Lovelock, C. E., Martinetto, P., Saunders, M. I., Pandolfi, J. M., et al. (in press). Reconsidering ocean calamities. Bioscience.

Duarte, C. M., Gasol, J. M., and Vaqué, D. (1997b). The role of experimental approaches in marine microbial ecology. Aquat. Microb. Ecol. 13, 101-111. doi: 10.3354/ame013101

Duarte, C. M., Holmer, M., Olsen, Y., Soto, D., Marbà, N., Guiu, J., et al. (2009a). Will the oceans help feed humanity? Bioscience 59, 967-976. doi: 10.1525/bio.2009.59.11.8

Duarte, C. M., Lenton, T. M., Wadhams, P., and Wassmann, P. (2012a). Abrupt climate change in the Arctic. Nat. Clim. Change 2, 60-62. doi: 10.1038/nclimate1386

Duarte, C. M., Marbà, N., and Holmer, M. (2007b). Rapid domestication of marine species. Science 316, 382-383. doi: 10.1126/science.1138042

Duarte, C. M., Marbà, N., Krause-Jensen, D., and Sánchez-Camacho, M. (2007a). Testing the predictive power of seagrass depth limit models. Estuar. Coasts 30, 652-656. doi: 10.1007/BF02841962

Duarte, C. M., Pitt, K. A., Lucas, C. H., Purcell, J. E., Uye, S.-i., Robinson, K., et al. (2012c). Is global ocean sprawl a cause of jellyfish blooms? Front. Ecol. Environ. 11, 91-97. doi: 10.1890/110246

Duce, R. A., LaRoche, J., Altieri, K., Arrigo, K. R., Baker, A. R., Capone, D. G., et al. (2008). Impacts of atmospheric anthropogenic nitrogen on the open ocean. Science 320, 893-897. doi: 10.1126/science. 1150369

Dunlap, R. E., and Van Liere K. D. (2008). The "New Environmental Paradigm." J. Environ. Edn. 40, 19-28.

Echeveste, P., Agustí, S., and Dachs, J. (2010a). Cell size dependent toxicity thresholds of polycyclic aromatic hydrocarbons to natural and cultured phytoplankton populations. Environ. Pollut. 158, 299-307. doi: 10.1016/j.envpol.2009.07.006

Echeveste, P., Dachs, J., Berrojaldiz, N., and Agustí, S. (2010b). Decrease in the abundance and viability of oceanic phytoplankton due to trace levels of complex mixtures of organic pollutants. Chemosphere 81, 61-168. doi: 10.1016/j.chemosphere.2010.06.072

Echeveste, P., Tovar-Sánchez, A., and Agustí, S. (2014) Tolerance of polar phytoplankton communities to metals. Environ. Pollut. 185, 188-195. doi: 10.1016/j.envpol.2013.10.029

Ellis, E. C., Kaplan, J. O., Fuller, D. Q., Vavrus, S. Goldewijk, K. K., and Verburg, P. H. (2013). Used planet: a global history. Proc. Natl. Acad. Sci. U.S.A 110, 7978-7985. doi: 10.1073/pnas. 1217241110

Erlandson, J. M., and Rick, T. C. (2010). Archaeology meets marine ecology: the antiquity of maritime cultures and human impacts on marine fisheries and ecosystems. Annu. Rev. Mar. Sci. 2, 231-251. doi: 10.1146/annurev.marine.010908.163749

Esteban, M., and Leary, D. (2012). Current developments and future prospects of offshore wind and ocean energy. Appl. Energy 90, 128-136. doi: 10.1016/j.apenergy.2011.06.011

European Union. (2011). Marine Strategy Framework Directive of the European Union. Available online at: http://eur-lex.europa.eu/legal-content/EN/ TXT/?uri=CELEX:32008L0056

Fargione, J. E., Plevin, R. J., and Hill, J. D. (2010). The ecological impact of biofuels. Annu. Rev. Ecol. Evol. Syst. 41, 351-377. doi: 10.1146/annurev-ecolsys102209-144720

Fetterer, F., Knowles, K., Meier, W., and Savoie, M. (2014). Sea Ice Index, Boulder: National Snow and Ice Data Center.

Frieler, K., Meinshausen, M., Golly, A., Mengel, M., Lebek, K., Donner, S. D., et al. (2012). Limiting global warming to $2^{\circ} \mathrm{C}$ is unlikely to save most coral reefs. Nat. Clim. Change 3, 165-170. doi: $10.1038 /$ nclimate 1674

Galil, B. S. (2009). Taking stock: inventory of alien species in the Mediterranean Sea. Biol. Invasions 11, 359-372. doi: 10.1007/s10530-008-9253-y

Galil, B. S., Nehring, S., and Panov, V. (2007). "Waterways as invasion highways-impact of climate change and globalization," in Biological Invasions, eds W. Nentwig, S. Bacher, M. J. W. Cock, H. Dietz, A. Gigon, and R. Wittenberg (Berlin; Heidelberg: Springer), 59-74.

Garnier-Laplace, J., Beaugelin-Seiller, K., and Hinton, T. G. (2011). Fukushima wildlife dose reconstruction signals ecological consequences. Environ. Sci. Technol. 45, 5077-5078. doi: 10.1021/es201637c

Gelcich, S., Buckley, P., Pinnegar, J. K., Terry, G., Chilvers, J., Lorenzoni, I., et al. (2014). Public awareness, concerns, and priorities of anthropogenic impacts on marine environments. Proc. Natl. Acad. Sci. U.S.A. 111, 15042-15047. doi: 10.1073/pnas.1417344111

Groffman, P., Stylinski, S., Nisbet, M. C., Duarte C. M., Jordan, R., Burgin, A., et al. (2010). Restarting the conversation: challenges at the interface between ecology and society. Front. Ecol. Environ. 8, 284-291. doi: 10.1890/090160

Gross, M. (2014). The deep sea under siege. Curr. Biol. 24, R137-R139. doi: 10.1016/j.cub.2014.01.062

Gruber, N. (2011). Warming up, turning sour, losing breath: ocean biogeochemistry under global change. Philos. Trans. R. Soc. A Math. Phys. Eng. Sci. 369, 1980-1996. doi: 10.1098/rsta.2011.0003

Häder, D. P., Kumar, H. D., Smith, R. C., and Worrest, R. C. (2007). Effects of solar UV radiation on aquatic ecosystems and interactions with climate change. Photochem. Photobiol. Sci. 6, 267-285. doi: 10.1039/b700020k

Håkanson, L. (1995). Optimal size of predictive models. Ecol. Model. 78, 195-204. doi: 10.1016/03043800(93)E0103-A

Hall-Spencer, J., Valerie, A., and Fosså, J. H. (2005). Trawling damage to Northeast Atlantic ancient coral reefs. Proc. R. Soc. Lond. Ser. B Biol. Sci. 269, 507-511. doi: 10.1098/rspb.2001.1910

Halpern, B. S., Walbridge, S., Selkoe, K. A., Kappel, C. V., Micheli, F., D’Agrosa, C., et al. (2008). A global map of human impact on marine ecosystems. Science 319, 948-952. doi: 10.1126/science. 1149345

Henderson, S. (1997). Black swans don't fly double loops: the limits of the learning organization? Learn. Organ. 4, 99-105. doi: 10.1108/09696479710182777

Hendriks, I. E., Duarte, C. M., and Álvarez, M. (2010). Vulnerability of marine biodiversity to ocean acidification: a meta-analysis. Estuar. Coast. Shelf Sci. 86, 157-164. doi: 10.1016/j.ecss.2009.11.022

Hendriks, I. E., Duarte, C. M., and Heip, C. H. R. (2006). Biodiversity research still grounded. Science 312:1715. doi: 10.1126/science.1128548

Hendriks, I. E., Duarte, C. M., Olsen, Y. S., Steckbauer, A., Ramajo, L., Moore, T. S., et al. (2014a). Biological mechanisms supporting adaptation to ocean acidification in coastal ecosystems. Estuar. Coast. Shelf Sci. doi: 10.1016/j.ecss.2014.07.019

Hendriks, I. E., Olsen, Y. S., Ramajo, L., Basso, L., Steckbauer, A., Moore, T. S., et al. (2014b). Photosynthetic activity buffers ocean acidification in seagrass meadows. Biogeosciences 11, 333-346. doi: 10.5194/bg-11-333-2014

Hilborn, R. (2006). Faith-based fisheries. Fisheries 31, $554-555$.

Hinkel, J., Lincke, D., Vafeidis, A. T., Perrette, M. Nicholls, R. J., Tol, R. S. J., et al. (2014). Coastal flood damage and adaptation costs under 21st century sea-level rise. Proc. Natl. Acad. Sci. U.S.A. 111, 3292-3297. doi: 10.1073/pnas.1222469111

Hofmann, G. E., and Todgham, A. E. (2010). Living in the now: physiological mechanisms to tolerate a rapidly changing environment. Annu. Rev. Physiol. 72, 127-145. doi: 10.1146/annurevphysiol-021909-135900

Holding, J. M., Duarte, C. M., Arrieta, J. M., VaquerSunyer, R., Coello-Camba, A., Wassmann, P. F., et al. (2013). Experimentally determined temperature thresholds for Arctic plankton community metabolism. Biogeosciences 10, 357-370. doi: 10.5194/bg-10-357-2013

Hughes, T. P., Baird, A. H., Bellwood, D. R., Card, M., Connolly, S. R., Folke, C., Grosberg, R., et al. (2003). Climate change, human impacts, and the resilience of coral reefs. Science 301, 929-933.

Ittekkot, V., Humborg, C., and Schäfer, P. (2000). Hydrological alterations and marine biogeochemistry: a silicate issue? silicate retention in reservoirs behind dams affects ecosystem structure in coastal seas. Bioscience 50, 776-782. doi: 10.1641/0006-3568(2000)050[0776:HAAMBA] 2.0.CO;2 
Jackson, J. B., Kirby, M. X., Berger, W. H., Bjorndal, K. A., Botsford, L. W., Bourque, B. J., et al. (2001). Historical overfishing and the recent collapse of coastal ecosystems. Science 293, 629-637. doi: $10.1126 /$ science. 1059199

Jentoft, S. (2007). Limits of governability: institutional implications for fisheries and coastal governance. Mar. Policy 31, 360-370. doi: 10.1016/j.marpol.2006.11.003

Jentoft, S., Onyango, P., and Islam, M. M. (2010). Freedom and poverty in the fishery commons. Int. J. Commons 4, 345-366.

Jordà, G., Marbà, N., and Duarte, C. M. (2012). Mediterranean seagrass vulnerable to regional climate warming. Nat. Clim. Change 2, 821-824. doi: 10.1038/nclimate 1533

Jurado, E., Dachs, J., Duarte, C. M., and Simo, R. (2008). Atmospheric deposition of organic and black carbon to the global oceans. Atmos. Environ. 42, 7931-7939. doi: 10.1016/j.atmosenv.2008.07.029

Jurado, E., Jaward, F., Lohmann, R., Jones, K. C., Simó, R., and Dachs, J. (2005). Wet deposition of persistent organic pollutants to the global oceans. Environ. Sci. Technol. 39, 2426-2435. doi: $10.1021 / \mathrm{es} 048599 \mathrm{~g}$

Jurado, E., Jaward, F. M., Lohmann, R., Jones, K. C., Simó, R., and Dachs, J. (2004). Atmospheric dry deposition of persistent organic pollutants to the Atlantic and inferences for the global oceans. Environ. Sci. Technol. 38, 5505-5513. doi: 10.1021/es049240v

Keeling, R. F., Körtzinger, A., and Gruber, N. (2010). Ocean deoxygenation in a warming world. Ann. Rev. Marine. Sci. 2, 199-229.

Ki-moon, B. (2012). UN Oceans Compact. Available online at: http://www.un.org/depts/los/ocean compact/oceans_compact.htm

Kovacs, K. M., Lydersen, C., Overland, J. E., and Moore, S. E. (2011). Impacts of changing seaice conditions on Arctic marine mammals. Mar. Biodivers. 41, 181-194. doi: 10.1007/s12526-0100061-0

Kroecker, K. J., Kordas, R. L., Crim, R., Hendriks, I. E., Ramajo, L., Singh, G. S., et al. (2013). Impacts of ocean acidification on marine organisms: quantifying sensitivities and interaction with warming. Glob. Change Biol. 19, 1884-1896. doi: $10.1111 / \mathrm{gcb} .12179$

Lee, S., Van Duc Long, N., and Lee, N. M. (2012). Design and optimization of natural gas liquefaction and recovery processes for offshore floating liquefied natural gas plants. Ind. Eng. Chem. Res. 51, 10021-10030. doi: 10.1021/ ie 2029283

Lenton, T. M., Held, H., Kriegler, E., Hall, J. W., Lucht, W., Rahmstorf, S., et al. (2008). Tipping elements in the Earth's climate system. Proc. Natl. Acad. Sci. U.S.A. 105, 1786-1793. doi: 10.1073/pnas.0705414105

Llabrés, M., Agustí, S., Fernández, M., Canepa, A., Maurin, F., Vidal, F., et al. (2013). Impact of elevated UVB radiation on marine biota: a meta-analysis. Glob Eco. Bio. 22, 131-144. doi: 10.1111/j.1466-8238.2012.00784.x

Lohbeck, K. T., Riebesell, U., and Reusch, T. B. H. (2012). Adaptive evolution of a key phytoplankton species to ocean acidification. Nat. Geosci. 5, 346-351. doi: 10.1038/ngeo1441
Lusty, P. A. J., and Gunn, A. G. (2014). Challenges to global mineral resource security and options for future supply. Geol. Soc. Lond. Spec. Pub. 393. doi: 10.1144/SP393.13

Macdonald-Ross, M. (1979). Scientific diagrams and the generation of plausible hypotheses: an essay in the history of ideas. Instruct. Sci. 8, 223-234. doi: 10.1007/BF00055241

Malthus, T. R. (1798). An Essay on the Principle of Population. London: J. Johnson.

Marbà, N., and Duarte, C. M. (2010). Mediterranean warming triggers seagrass (Posidonia oceanica) shoot mortality. Glob. Change Biol. 16, 2366-2375. doi: 10.1111/j.1365-2486.2009.02130.x

Marean, C. W., Bar-Matthews, M., Bernatchez, J., Fisher, E., Goldberg, P., Herries, A. I., et al. (2007). Early human use of marine resources and pigment in South Africa during the Middle Pleistocene. Nature 449, 905-908. doi: 10.1038/nature06204

McCulloch, M., Falter, J., Trotter, J., and Montagna, P. (2012). Coral resilience to ocean acidification and global warming through $\mathrm{pH}$ up-regulation. Nat. Clim. Change 2, 623-627. doi: 10.1038/nclimate 1473

Medina, M. H., Correa, J. A., and Barata, C. (2007). Micro-evolution due to pollution: possible consequences for ecosystem responses to toxic stress. Chemosphere 67, 2105-2114. doi: 10.1016/j.chemosphere.2006.12.024

Meehl, G. A., Stocker, T. F., Collins, W. D., Friedlingstein, P., Gaye, A. T., Gregory, J. M., et al. (2007). "Global climate projections," in Climate Change 2007: The Physical Science Basis. Contribution of Working Group I to the Fourth Assessment Report of the Intergovernmental Panel on Climate Change, eds S. D. Solomon, M. Qin, Z. Manning, M. Chen, K. B. Marquis, M. Averyt et al. (Cambridge, UK; New York, NY: Cambridge University Press), 748-845.

Mengerink, K. J., Van Dover, C. L., Ardron, J., Baker, M., Escobar-Briones, E., Gjerde, K., et al. (2014). A call for deep-ocean stewardship. Science 344, 696-698. doi: 10.1126/science. 1251458

Merton, R. K. (1973). The Sociology of Science: Theoretical and Empirical Investigations. Chicago: University of Chicago press.

Moss, R. H., Edmonds, J. A., Hibbard, K. A., Manning, M. R., Rose, S. K., Van Vuuren, D. P., et al. (2010). The next generation of scenarios for climate change research and assessment. Nature 463 , 747-756. doi: 10.1038/nature08823

Nicholls, R. J., Marinova, N., Lowe, J. A., Brown, S., Vellinga, P., De Gusmao, D., et al. (2011). Sea-level rise and its possible impacts given a "beyond $4 \mathrm{C}$ world" in the twenty-first century. Philos. Trans. R. Soc. A Math. Phys. Eng. Sci. 369, 161-181. doi: 10.1098/rsta.2010.0291

O'Connor, M. I., Holding, J., Kappel, C. V., Duarte, C. M., Brander, K., Brown, C. J., et al. (2014). Strengthening confidence in climate impacts science. Global Ecol. Biogeogr. doi: 10.1111/geb.12218

O'Connor, S., Ono, R., and Clarkson, C. (2011). Pelagic fishing at 42,000 years before the present and the maritime skills of modern humans. Science 334, 1117-1121. doi: 10.1126/science. 1207703

Obama, B. (2010). Executive Order 13547 on the Stewardship of the Ocean, Our Coasts, and the Great Lakes (2010). Available online at: http:// www.whitehouse.gov/the-press-office/executive- order - stewardship - ocean - our - coasts-and-greatlakes

Orr, J. C., Fabry, V. J., Aumont, O., Bopp, L., Doney, S. C., Feely, R. A., et al. (2005). Anthropogenic ocean acidification over the twenty-first century and its impact on calcifying organisms. Nature 437, 681-686. doi: 10.1038/nature04095

Overland, J. E., Wang, M., Walsh, J. E., and Stroeve, J. C. (2014). Future Arctic climate changes: adaptation and mitigation time scales. Earths Future 2, 68-74. doi: 10.1002/2013EF000162

Pandolfi, J. M., Connolly, S. R., Marshall, D. J., and Cohen, A. L. (2011). Projecting coral reef futures under global warming and ocean acidification. Science 333, 418-422. doi: 10.1126/science. 1204794

Panjabi, R. K. L. (2009). Pirates of Somalia: Opportunistic Predators or Environmental Prey. William. \& Mary Envtl. Law Policy Rev. 34, 377-484.

Pauly, D., Christensen, V., Dalsgaard, J., Froese, R., and Torres, F. (1998). Fishing down marine food webs. Science 279, 860-863. doi: 10.1126/science.279.5352.860

Peñate, L., Martín, O., Cárdenas, R., and Agustí, S. (2010). Short-term effects of Gamma Ray Bursts on oceanic photosynthesis. Astrophys. Space Sci. 330, 211-217. doi: 10.1007/s10509-010-0450-7

Pereira, H. M., Leadley, P. W., Proença, V., Alkemade, R., Scharlemann, J. P. W., Fernandez-Manjarrés, J. F., et al. (2010). Scenarios for global biodiversity in the 21st century. Science 330, 1496-1501. doi: 10.1126/science.1196624

Platt, J. R. (1964). Strong inference. Science 146, 347-353. doi: 10.1126/science.146.3642.347

Polasky, S., Carpenter, S. R., Folke, C., and Keeler, B. (2011). Decision-making under great uncertainty: environmental management in an era of global change. Trends Ecol. Evol. 26:398-404. doi: 10.1016/j.tree.2011.04.007

Poloczanska, E. S., Brown, C. J., Sydeman, W. J., Kiessling, W., Schoeman, D. S., Moore, P. J., et al. (2013). Global imprint of climate change on marine life. Nat. Clim. Change 3, 919-925. doi: 10.1038/nclimate 1958

Puig, P., Canals, M., Company, J. B., Martín, J., Amblas, D., Lastras, G., et al. (2012). Ploughing the deep sea floor. Nature 489, 286-289. doi: 10.1038 /nature 11410

Pusceddu, A., Bianchelli, S., Martín, J., Puig, P., Palanques, A., Masqué, P., et al. (2014). Chronic and intensive bottom trawling impairs deepsea biodiversity and ecosystem functioning. Proc. Nat. Acad. Sci. U.S.A. 111, 8861-8866. doi: 10.1073/pnas.1405454111

Ramos, J., Domínguez-Bella, S., Cantillo, J. J., Soriguer, M., Pérez, M., Hernando, J., et al. (2011). Marine resources exploitation by Palaeolithic hunter-fisher-gatherers and Neolithic tribal societies in the historical region of the Strait of Gibraltar. Quatern. Int. 239, 104-113. doi: 10.1016/j.quaint.2011.03.015

Regaudie-de-Gioux, A., and Duarte, C. M (2012). Temperature dependence of planktonic metabolism in the ocean. Glob. Biogeochem. Cycles 26, 186. doi: 10.1029/2010GB003907

Richardson, A. J., and Poloczanska, E. S. (2008). Under-resourced, under threat. Science 320:1294. doi: $10.1126 /$ science.1156129 
Ries, J. B., Cohen, A. L., and McCorkle, D. C. (2009). Marine calcifiers exhibit mixed responses to $\mathrm{CO}_{2}$-induced ocean acidification. Geology 37, 1131-1134. doi: 10.1130/ G30210A.1

Rockström, J., Steffen, W., Noone, K., Persson, A., Chapin, F. S., Lambin, E. F., et al. (2009). A safe operating space for humanity. Nature 461, 472-475. doi: 10.1038/461472a

Rosman, K. J. R., Chisholm, W., Hong, S., Candelone, J.-P., and Boutron, C. F. (1997). Lead from Carthaginian and Roman Spanish mines isotopically identified in Greenland ice dated from $600 \mathrm{BC}$ to 300 AD. Environ. Sci. Technol. 31, 3413-3416. doi: $10.1021 /$ es $970038 \mathrm{k}$

Rudd, M. A. (2014). Scientists' perspectives on global ocean research priorities. Front. Mar. Sci. 1:36. doi: 10.3389/fmars.2014.00036

Ruiz, G. M., Fofonoff, P. W., Carlton, J. T., Wonham, M. J., and Hines, A. H. (2000). Invasion of coastal marine communities in North America: apparent patterns, processes, and biases. Annu. Rev. Ecol. Syst. 31, 481-531. doi: 10.1146/annurev.ecolsys. 31.1.481

Schulte, P., Alegret, L., Arenillas, I., Arz, J. A., Barton, P. J., Bown, P. R., et al. (2010). The Chicxulub asteroid impact and mass extinction at the CretaceousPaleogene boundary. Science 327, 1214-1218. doi: 10.1126/science. 1177265

Schlüter, L., Lohbeck, K. T., Gutowska, M. A., Gröger, J. P., Riebesell, U., and Reusch, T. B. (2014). Adaptation of a globally important coccolithophore to ocean warming and acidification. Nat. Clim. Change 4, 1024-1030. doi: 10.1038/nclimate2379

Seebens, H., Gastner, M. T., and Blasius, B. (2013). The risk of marine bioinvasion caused by global shipping. Ecol. Lett. 16, 782-790. doi: 10.1111/ele.12111

Small, C., and Cohen, J. E. (2004). Continental physiography, climate, and the global distribution of human population. Curr. Anthropol. 45, 269-277. doi: $10.1086 / 382255$

Smith, L. C., and Stephenson, S. R. (2013). New transArctic shipping routes navigable by midcentury. Proc. Natl. Acad. Sci. U.S.A. 110, E1191-E1195. doi: 10.1073/pnas. 1214212110

Solomon, S. (2004). The hole truth. Nature 427, 289-291. doi: 10.1038/427289a

Sood, A., and Smakhtin, V. (2014). Can desalination and clean energy combined help to alleviate global water scarcity? J. Am. Water Res. Assoc. 1-13. doi: 10.1111/jawr.12174
Steckbauer, A., Duarte, C. M., Carstensen, J., VaquerSunyer, R., and Conley, D. J. (2011). Ecosystem impacts of hypoxia: thresholds of hypoxia and pathways to recovery. Environ. Res. Lett. 6:025003. doi: 10.1088/1748-9326/6/2/025003

Steffen, W., Sanderson, R. A., Tyson, P. D., Jäger, J., Matson, P. A., Moore, B. III., et al. (2006). Global Change and the Earth System: A Planet Under Pressure, Berlin: Springer.

Stephenson, S. R., Smith, L. C., Brigham, L. W., and Agnew, J. A. (2013). Projected 21st-century changes to Arctic marine access. Clim. Change 118, 885-899. doi: 10.1007/s10584-012-0685-0

Sterman, J. D. (2008). Risk communication on climate: mental models and mass balance. Science 322, 532-533. doi: 10.1126/science. 1162574

Stramma, L., Prince, E. D., Schmidtko, S., Luo, J., Hoolihan, J. P., Visbeck, M., et al. (2012). Expansion of oxygen minimum zones may reduce available habitat for tropical pelagic fishes. Nat. Clim. Change 2, 33-37. doi: 10.1038/nclimate 1304

Sun, Y., Lü, X., and Guo, W. (2014). A review on simulation models for exploration and exploitation of natural gas hydrate. Arab. J. Geosci. 7, 2199-2214. doi: 10.1007/s12517-014-1294-1

Sunday, J. M., Calosi, P., Dupont, S., Munday, P. L., Stillman, J. H., and Reusch, T. B. H. (2014). Evolution in an acidifying ocean. Trends Ecol. Evol. 29, 117-125. doi: 10.1016/j.tree.2013.11.001

Tol, R. S. J., Klein, R. J. T., and Nichols, R. J. (2008). Towards successful adaptation to sea-level rise along Europe's coasts. J. Coast. Res. 24, 432-442. doi: 10.2112/07A-0016.1

Tovar-Sánchez, A., Serón, J., Marbà, N., Arrieta, J. M., and Duarte, C. M. (2010). Long-term records of trace metal content of western Mediterranean seagrass (Posidonia oceanica) meadows: natural and anthropogenic contributions. J. Geophys. Res. Biogeosci. 115, G02006. doi: 10.1029/2009JG001076

United Nations. (2004). UN Population to 2300. United Nations.

Valery, P. (1937). Notre Destin et Les Lettres. Journal de l'université des Annales 19, 341-354.

Van Dover, C. L., Aronson, J., Pendleton, L., Smith, S., Arnaud-Haond, S., Moreno-Mateos, D., et al. (2013). Ecological restoration in the deep sea: desiderata. Mar. Policy 44, 98-106. doi: 10.1016/j.marpol.2013.07.006

Vaquer-Sunyer, R., and Duarte, C. M. (2008). Thresholds of hypoxia for marine biodiversity. Proc. Nat. Acad. Sci. U.S.A. 105, 15452-15457. doi: 10.1073/pnas.0803833105
Vaquer-Sunyer, R., and Duarte, C. M. (2010). Sulfide exposure accelerates hypoxia-driven mortality. Limnol. Oceanogr. 55, 1075-1082. doi: 10.4319/lo.2010.55.3.1075

Vaquer-Sunyer, R., and Duarte, C. M. (2011). Temperature effects on oxygen thresholds for hypoxia in marine benthic organisms. Glob. Change Biol. 17, 1788-1797. doi: 10.1111/j.13652486.2010.02343.x

Visser, M. E. (2008). Keeping up with a warming world; assessing the rate of adaptation to climate change. Proc. R. Soc. Lond. B Biol. Sci. 275, 649-659. doi: 10.1098/rspb.2007.0997

Walling, D. E. (2006). Human impact on landocean sediment transfer by the world's rivers. Geomorphology 79, 192-216. doi: 10.1016/j.geomorph.2006.06.019

Wang, M., and Overland, J. E. (2012). A sea ice free summer Arctic within 30 years: an update from CMIP5 models. Geophys. Res. Lett. 39, L18501. doi: 10.1029/2012GL052868

Wassmann, P. F., Duarte, C. M., Agusti, S and Sejr, M. K. (2011). Footprints of climate change in the Arctic marine ecosystem. Glob. Change Biol. 17, 1235-1249. doi: 10.1111/j.1365-2486.2010.02311.x

Wintle, B. A., Runge, M. C., and Bekessy, S. A. (2010). Allocating monitoring effort in the face of unknown unknowns. Ecol. Lett. 13, 1325-1337. doi: 10.1111/j.1461-0248.2010.01514.x

Conflict of Interest Statement: The author declares that the research was conducted in the absence of any commercial or financial relationships that could be construed as a potential conflict of interest.

Received: 19 August 2014; accepted: 04 November 2014; published online: 02 December 2014.

Citation: Duarte CM (2014) Global change and the future ocean: a grand challenge for marine sciences. Front. Mar. Sci. 1:63. doi: 10.3389/fmars.2014.00063

This article was submitted to Global Change and the Future Ocean, a section of the journal Frontiers in Marine Science.

Copyright (c) 2014 Duarte. This is an open-access article distributed under the terms of the Creative Commons Attribution License (CC BY). The use, distribution or reproduction in other forums is permitted, provided the original author(s) or licensor are credited and that the original publication in this journal is cited, in accordance with accepted academic practice. No use, distribution or reproduction is permitted which does not comply with these terms. 